\title{
Progress in the Development of Electrodeposited Catalysts for Direct Liquid Fuel Cell Applications
}

\author{
Kranthi Kumar Maniam ${ }^{1, *}$, Raghuram Chetty ${ }^{2}$ (D), Ravikumar Thimmappa ${ }^{3}$ and Shiladitya Paul ${ }^{1,4, *(D)}$ \\ 1 Materials Innovation Centre, School of Engineering, University of Leicester, Leicester LE1 7RH, UK \\ 2 Department of Chemical Engineering, Indian Institute of Technology Madras, Chennai 600 036, India; \\ raghuc@iitm.ac.in \\ 3 School of Engineering, Newcastle University, Newcastle upon Tyne NE1 7RU, UK; \\ kumar.ravikumar@ncl.ac.uk \\ 4 Materials and Structural and Integrity Technology Group, TWI, Cambridge CB21 6AL, UK \\ * Correspondence: km508@leicester.ac.uk (K.K.M.); shiladitya.paul@twi.co.uk (S.P.)
}

check for updates

Citation: Maniam, K.K.; Chetty, R.; Thimmappa, R.; Paul, S. Progress in the Development of Electrodeposited Catalysts for Direct Liquid Fuel Cell Applications. Appl. Sci. 2022, 12, 501. https://doi.org/10.3390/ app12010501

Academic Editor: Valentina Belova

Received: 9 November 2021

Accepted: 26 December 2021

Published: 5 January 2022

Publisher's Note: MDPI stays neutral with regard to jurisdictional claims in published maps and institutional affiliations.

Copyright: (C) 2022 by the authors. Licensee MDPI, Basel, Switzerland. This article is an open access article distributed under the terms and conditions of the Creative Commons Attribution (CC BY) license (https:// creativecommons.org/licenses/by/ $4.0 /)$.

\begin{abstract}
Fuel cells are a key enabling technology for the future economy, thereby providing power to portable, stationary, and transportation applications, which can be considered an important contributor towards reducing the high dependencies on fossil fuels. Electrocatalyst plays a vital role in improving the performance of the low temperature fuel cells. Noble metals (Pt, Pd) supported on carbon have shown promising performance owing to their high catalytic activity for both electroreduction and electrooxidation and have good stability. Catalyst preparation by electrodeposition is considered to be simple in terms of operation and scalability with relatively low cost to obtain high purity metal deposits. This review emphasises the role of electrodeposition as a cost-effective method for synthesising fuel cell catalysts, summarising the progress in the electrodeposited Pt and Pd catalysts for direct liquid fuel cells (DLFCs). Moreover, this review also discusses the technological advances made utilising these catalysts in the past three decades, and the factors that impede the technological advancement of the electrodeposition process are presented. The challenges and the fundamental research strategies needed to achieve the commercial potential of electrodeposition as an economical, efficient methodology for synthesising fuel cells catalysts are outlined with the necessary raw materials considering current and future savings scenario.
\end{abstract}

Keywords: direct liquid fuel cells; electrodeposition; oxidation; oxygen reduction reaction; ionic liquids; deep eutectic solvents

\section{Introduction}

Direct liquid fuel cells (DLFCs) involving organic molecules are attractive power sources for portable applications due to their high theoretical energy density of fuels, rapid refueling, mild operating conditions, and simple cell design. Renewable energy generation is not always continuous and intermittent, which opens spatial and temporal gaps between the availability of the energy and its consumption by end-users [1]. In order to address these issues, it is necessary to develop suitable energy storage systems for the power grids. The energy storage system ensures the stability of the energy supply for the renewable sources [2]. As the DLFCs possess excellent features such as (i) high theoretical energy density, (ii) simplicity in handling, management, and storage, (iii) modest cell configuration with mild operating conditions, these continue to serve as potential energy storage and conversion devices and contribute to the renewable energy sector [3]. Electrochemical reactions in DLFCs are critical, and most of the fuel cell research is focused on a better understanding of their mechanism and the development of efficient electrocatalysts. Noble metal catalysts, such as platinum $(\mathrm{Pt})$ and $\mathrm{Pt}$-based alloys, are used to accelerate the electrochemical reaction rate and are dispersed on porous electrodes. 
Despite the fact that the high costs and scarcity of noble metal reserves have predominantly limited their use, Pt-based catalysts continue to dominate in improving the performance of fuel cell reactions involving organic molecules used as direct fuels. The United States Department of Energy (DOE) has supported the fuel cell research and technology development through hydrogen and fuel cell programme, to address major technical barriers and enable widespread industrialization of the technology for a variety of applications. The DOE price target for a fuel cell system for automotive vehicles is $\$ 40$ per $\mathrm{kW}$ by 2025 , with an ultimate cost of $\$ 30$ per $\mathrm{kW}$ beyond 2030. Most standard membrane electrode assemblies (MEAs) have an average platinum catalyst loading of $0.2-0.25 \mathrm{mg} \mathrm{Pt} \mathrm{cm}^{-2}$ [4]. The durability target for a fuel cell system for automotive vehicles is $5000 \mathrm{~h}$ for 2025 , with an ultimate goal of $8000 \mathrm{~h}$. Under the support of the DOE and other country trade associations such as Japan's Ministry of Economy, Trade, and Industry (METI), the DOE's national laboratories and others have been carrying out cutting-edge research in collaboration with industry and academia [5]. Consequently, reducing the use of noble metals, particularly Pt, and improving their utilisation efficiencies by rationally designing electrocatalysts with superior catalytic properties is a critical strategy for the large-scale commercial application of DLFCs.

It has been deduced and identified that the cost of catalyst contributes around $41 \%$ of the total cost of the fuel cell when compared to its other components, such as the bipolar plate, polymer membrane, gaskets, gas diffusion layer, electrodes, and the balance of plant [6]. The preparation method of catalysts (metals, metal-alloys) influences the structural, compositional, and morphological characteristics and performance of fuel cell reactions [7]. The utilisation of current Pt, Pd catalyst synthesis methods such as modified polyol, chemical reduction, colloidal approach, and so on necessitates repeated filtering and washing. These methods are time-consuming and frequently result in metal particle loss. The chemical approach used to synthesize these catalysts increases particle size and metal aggregation.

Catalyst supported on carbon with narrow particle distribution is expected to improve the fuel cell reaction performance with minimum catalyst loading. Under such circumstances, electrochemical deposition is advocated as a cost-effective alternative synthesis method for obtaining metal particles of different crystalline nature (crystalline/amorphous) with various shapes, sizes without any post-processing requirement. This methodology offers certain key benefits such as mild operating conditions, high purity, relatively low cost, eliminating repetitive filtering and washing process [8,9]. Non-electrodeposition methods for synthesis of shape-controlled catalysts were limited as they rely on template techniques involving organic surfactants, polymeric substances with stabilisation effects at elevated temperatures, and the utilisation of structure-directing agents to control the porosity. The addition of these additives makes the current wet chemical processes difficult in obtaining pure products. While the quest for low-cost electrodes for fuel cells has been a focus of attention, extensive efforts have been made to investigate carbon decorated with electrodeposited noble metals as electrodes [10]. The advantage with electrodeposition methods is the possibility of synthesizing metal particles with different shapes, structures preferred orientation through tailoring the applied current, potential, electrolyte conditions.

Despite the fact that $\mathrm{Pt}$ is the most advanced catalyst for low temperature DLFCs, its applicability is hampered by two main technological gaps: cost and long-term stability. Although practical ways to reduce cost and increase performance have been devised, the true breakthrough is yet to be realised. Currently, two approaches are being pursued to lower catalyst costs: investigating cost-effective non-Pt catalysts and reducing Pt loading. An ambitious strategy for cost reduction in fuel cells is to entirely replace Pt with less expensive materials while maintaining the catalytic activity [11]. Palladium (Pd) has received considerable attention in fuel cell research as an alternative to $\mathrm{Pt}$ because of its relative abundance and low cost. Pd is used in fuel cells, synthesis of organic compounds, hydrogen storage, automobile and sensing, and other industrial applications [12,13]. Pd plays a good role in various electrochemical reactions involving electro-oxidation of different fuels and oxygen reduction. Anodic oxidation of organic molecules such as ethanol and formic acid are important reactions, and $\mathrm{Pd}$ catalysts have proven to be much more active than $\mathrm{Pt}$ 
in direct formic acid fuel cells [14]. Prior research works on single crystal Pd electrodes demonstrated that the oxidation reaction of formic acid is structure sensitive, suggesting that the facets represented on the surface of a catalyst can have a major impact. Because of their superior methanol tolerance in PEM based direct methanol fuel cells (DMFCs) and increased activity, Pd-based nanoparticles are regarded as ideal alternative catalysts for oxygen reduction reactions (ORR). In an analytic data study conducted by Ojemaye et al., it was shown that there are 4674 articles that were reported focusing on the development of $\mathrm{Pt}$, $\mathrm{Pd}$ catalysts for fuel cell applications in the past 3 decades covering the period from 1990-2019 [15], signifying the field of interest. Table 1 lists the most commonly studied DLFCs and their associated electrochemical reactions.

Table 1. Table listing the DLFCs that are most commonly studied and associated electrochemical reactions involving supported Pd catalysts. Reprinted with permission from [16].

\begin{tabular}{cccc}
\hline Type of DLFC & Anode Reaction & Cathode Reaction & Overall Reaction \\
\hline DMFC $^{1}$ & $\mathrm{CH}_{3} \mathrm{OH}+\mathrm{H}_{2} \mathrm{O} \rightarrow \mathrm{CO}_{2}+6 \mathrm{H}^{+}+6 \mathrm{e}^{-}$ & $3 / 2 \mathrm{O}_{2}+6 \mathrm{H}^{+}+6 \mathrm{e}^{-} \rightarrow 3 \mathrm{H}_{2} \mathrm{O}$ & $\mathrm{CH}_{3} \mathrm{OH}+3 / 2 \mathrm{O}_{2} \rightarrow \mathrm{CO}_{2}+2 \mathrm{H}_{2} \mathrm{O}$ \\
\hline DEFC $^{2}$ & $\mathrm{C}_{2} \mathrm{H}_{5} \mathrm{OH}+3 \mathrm{H}_{2} \mathrm{O} \rightarrow 2 \mathrm{CO}_{2}+12 \mathrm{H}^{+}+12 \mathrm{e}^{-}$ & $3 \mathrm{O}_{2}+12 \mathrm{H}^{+}+6 \mathrm{e}^{-} \rightarrow 3 \mathrm{H}_{2} \mathrm{O}$ & $\mathrm{C}_{2} \mathrm{H}_{5} \mathrm{OH}_{3}+3 \mathrm{H}_{2} \mathrm{O} \rightarrow 2 \mathrm{CO}_{2}+3 \mathrm{H}_{2} \mathrm{O}$ \\
\hline DFAFC $^{3}$ & $\mathrm{HCOOH}+\mathrm{H}_{2} \mathrm{O} \rightarrow \mathrm{CO}_{2}+2 \mathrm{H}^{+}+2 \mathrm{e}^{-}$ & $1 / 2 \mathrm{O}_{2}+2 \mathrm{H}^{+}+2 \mathrm{e}^{-} \rightarrow \mathrm{H}_{2} \mathrm{O}$ & $\mathrm{HCOOH}+1 / 2 \mathrm{O}_{2} \rightarrow \mathrm{CO}_{2}+\mathrm{H}_{2} \mathrm{O}$ \\
\hline DEGFC $^{4}$ & $\mathrm{C}_{2} \mathrm{H}_{6} \mathrm{O}_{2}+2 \mathrm{H}_{2} \mathrm{O} \rightarrow 2 \mathrm{CO}_{2}+10 \mathrm{H}^{+}+10 \mathrm{e}^{-}$ & $5 / 2 \mathrm{O}_{2}+10 \mathrm{H}^{+}+10 \mathrm{e}^{-} \rightarrow 10 \mathrm{H}_{2} \mathrm{O}$ & $\mathrm{C}_{2} \mathrm{H}_{6} \mathrm{O}_{2}+2 \mathrm{H}_{2} \mathrm{O} \rightarrow 2 \mathrm{CO}_{2}+5 \mathrm{H}_{2} \mathrm{O}$ \\
\hline DGFC $^{5}$ & $\mathrm{C}_{3} \mathrm{H}_{8} \mathrm{O}_{3}+3 \mathrm{H}_{2} \mathrm{O} \rightarrow 3 \mathrm{CO}_{2}+14 \mathrm{H}^{+}+14 \mathrm{e}^{-}$ & $3 / 2 \mathrm{O}_{2}+6 \mathrm{H}^{+}+6 \mathrm{e}^{-} \rightarrow 3 \mathrm{H}_{2} \mathrm{O}$ & $\mathrm{C}_{3} \mathrm{H}_{8} \mathrm{O}_{3}+7 / 2 \mathrm{O}_{2} \rightarrow 3 \mathrm{CO}_{2}+4 \mathrm{H}_{2} \mathrm{O}$ \\
\hline & \multicolumn{4}{l}{ DMFC: Direct Methanol Fuel Cells; ${ }^{2}$ DEFC: Direct Ethanol Fuel Cells; ${ }^{3}$ DFAFC: Direct Formic Acid Fuel Cells; } \\
& &
\end{tabular}

The objective of this review is to present an overview of the progress made in the development of noble metal electrocatalysts prepared by electrodeposition for low temperature DLFCs. While several comprehensive review articles and books about the polymer electrolyte membrane fuel cells (PEMFC) electrocatalysts have been published over the past decade, most of them discussed the overall catalyst developments [5,13,17-23]. Detailed reviews consolidating the summary of the progress in the synthesis of Pt and Pd catalysts by electrodeposition are still scarce. This review discusses the advances in electrodeposition techniques focusing on noble metals as catalysts for low-temperature DLFCs, summarizing the research findings in the field so far. Economic considerations, future perspectives, the need for further exploitation, novel technologies, and further research are discussed in detail.

\section{Progress in the Electrodeposition of Carbon Supported Pt and Pd Catalysts}

It is well known that the performance of an electrocatalyst is strongly dependent on the method of its preparation. Besides the preparation methods, the performance of the catalyst is evaluated in terms of its activity towards reactions, which increases with increase in its active surface area and decrease in size of the metal particle $[24,25]$. Therefore, the catalysts are supported on high surface area conductive carbon substrates to improve their dispersion while maintaining the specific activity. Carbon supports, especially Vulcan, synthesized from the pyrolysis of hydrocarbons and having polycrystalline particle nature was widely used as a support for Pt and Pd catalysts in low temperature fuel cells. Vulcan support is resistant to corrosion and has a high surface area. Metal catalysts are typically synthesized as nanoparticles for obtaining a high surface area. These nanoparticles are essential to be formed in the porous electrodes for effectively promoting reactions in electrocatalytic applications such as fuel cells and sensors [26].

Since the catalysts are bonded to support, the support (typically carbon-based) will influence the activity of the catalyst potentially, which in turn depends on the method of preparation of the metal catalyst. The presence of finely distributed catalyst metal particles on support facilitates mass transfer of the fuel/oxidant into the pores and release of products at the catalyst surface. Various synthesis methods of preparation have been adopted to improve the dispersion of noble metal particles supported on different carbon- 
based substrates. This section will focus on developing electrodeposited noble metal ( $\mathrm{Pt}$ and Pd) catalysts supported on carbon and carbon-based materials.

\subsection{Electrodeposition of Pt}

Electrochemical deposition of precious metals is a method that involves the reduction of the desired metal ions from solution to the metallic state on the surface of a substrate in aqueous electrolytes [27]. Gloaguen et al. [28] carried out the electrooxidation of methanol utilising Pt nanoparticles onto porous carbon substrates obtained by potential step electrodeposition experiments. The purpose of the work was to determine the characteristics of Pt electrodeposited on various carbon supports, viz., graphite powder and conventional carbon, mixed with recast Nafion. Besides the effect of surface oxides, the influence of $\mathrm{Pt}$ specific surface area on methanol oxidation at various carbon supported $\mathrm{Pt} /$ recast Nafion was investigated. The experimental results obtained in this work for the methanol oxidation suggested that the Pt activity is more likely related to the fine Pt surface structures but not to the particle size. The fine structure, in turn, might be influenced by the Pt specific surface area, the nature of substrate, or the preparation procedure of the catalyst.

In general, electrocatalysts synthesized by wet-chemical synthesis can be deposited at the membrane-electrode interface in two different ways: (i) direct coating of catalyst onto the membrane and (ii) application of catalyst ink on the carbon substrate (carbon paper/carbon cloth). Direct application on the solid membrane creates a thin electrocatalyst layer resulting in a low catalyst loading and good mass transport properties. In contrast, the application of catalyst ink on the substrate may require a higher catalyst loading since the catalyst ink tends to penetrate into the substrate, resulting in inactive sites where no ionic contact is established [29]. When the catalyst loading is lowered, maintaining or improving catalyst performance towards fuel cell reactions becomes extremely challenging. In order to achieve this, several efforts were devoted towards the utilization of $\mathrm{Pt}$ and the enhancement of catalyst activity [30]. The specific surface area of a metal catalyst will determine the utilization efficiency of metal towards a particular fuel cell reaction. Improving the noble metal particle utilization will extend the three-phase boundary (a region where reactant, catalyst, and electrolyte are in contact), which in turn increases the specific surface area of the metal catalyst.

Efforts to decrease Pt loading through increased Pt utilization have resulted in the development of several novel methods. These can be broadly categorized into two groups: one is to use new materials to construct the catalyst layer, and the other is to optimize the structure of the catalyst layer, increase its utility and minimize irreversible losses. The former can be accomplished by modification of supported Pt. The latter is achieved by optimizing the structure of the catalyst layer using different fabrication methods and materials. The effective utilization of Pt nanoparticles towards the electrochemical reactions is strongly dependant on the contact between the membrane (PEM) and the noble metal Pt, i.e., on the thickness of the catalyst layer. Increasing the thickness of the catalyst layer will reduce the utilization efficiency of the catalyst. In general, the thickness of the catalyst layer depends on the nature of the carbon-coated substrates, i.e., on the hydrophobic/hydrophilic nature. If the nature of the substrate is hydrophilic, then the electrolyte would penetrate more deeply, resulting in the formation of a thick layer. On the other hand, the deposition would occur within a very narrow layer in the case of hydrophobic carbon substrates. To overcome this problem, Kim et al. [31] developed a novel method to control the thickness of the catalyst layer. A hydrophobic layer of carbon ink, prepared by mixing pretreated Vulcan and isopropanol in a supersonic mixer, was coated on the carbon cloth. Glycerol was added to the above mixture and sprayed on the hydrophobic layer. The resulting uncatalysed carbon electrode consisted of two layers, i.e., a hydrophobic layer followed by a hydrophilic layer. Pulse electrodeposition was employed to deposit $\mathrm{Pt}$ from $\mathrm{H}_{2} \mathrm{PtCl}_{6}$ and $\mathrm{HCl}$ on the carbon substrate. The catalyst so synthesized was used as the cathode, and $\mathrm{Pt} / \mathrm{C}$ from E-TEK was used as the anode. Back scattered scanning electron microscopy (SEM) image showed that the thickness of the cathode catalyst is lower than that of the 
anode catalyst layer. Electron probe microanalysis studies showed the concentration profile of pulse electrodeposited $\mathrm{Pt}$ decayed with increasing distance from the membrane to gas diffusion layer (GDL). In contrast, a uniform profile was observed in the E-TEK anode. Fuel cell polarization studies showed that the MEA containing the pulsed electrodeposited $\mathrm{Pt}$ cathode (Pt loading- $0.32 \mathrm{mg} \mathrm{cm}^{-2}$ ) displayed higher current densities at lower Pt loadings than that of the commercial Pt/C catalyst powder coated electrodes (TKK-46 wt \%; Pt loading $-0.40 \mathrm{mg} \mathrm{cm}^{-2}$ ) at a given potential when operated under same conditions.

Wei and Chen [32] aimed at increasing the utilization of Pt catalysts by lowering the catalyst loadings in the electrode. The study emphasised on the electrodeposition of Pt on an uncatalysed carbon electrode (UCE), i.e., glassy carbon (GC) rotating disc electrode (RDE) coated with a thin layer of Nafion-bonded Vulcan from an aqueous chloroplatinic acid $\left(\mathrm{H}_{2} \mathrm{PtCl}_{6}\right)$ solution. Moreover, the influence of Nafion content on the effective utilization of $\mathrm{Pt}$ particles towards oxygen reduction reaction (ORR) was also studied. Firstly, the behaviour of GC RDE and Pt RDE (a layer of 20 wt \% Pt/C commercial E-TEK catalyst bonded with Nafion on RDE) were studied in an aqueous $\mathrm{H}_{2} \mathrm{PtCl}_{6}$ solution with $\mathrm{HCl}$ as the supporting electrolyte. Secondly, Pt was electrodeposited on both the electrodes and the electrocatalytic ability of the prepared electrodes towards ORR was tested. The authors concluded that the Pt RDE exhibited a better ORR activity than the $20 \mathrm{wt} \%$ $\mathrm{Pt} / \mathrm{C}$ commercial E-TEK catalyst due to its Pt deposition at the carbon support-electrolyte interface. Such an improvement was primarily related to the increased utility of Pt. The findings demonstrated a very low current efficiency for Pt deposition under acidic aqueous conditions, where hydrogen evolution was unavoidable. Since then, there have been many efforts and attempts to decrease the Pt catalyst loading while increasing the mass activity.

Loffler et al. [33] developed a new method for depositing Pt nanoparticles on glassy carbon substrate using different $\mathrm{Pt}$ precursor salts by electrodeposition. A platinum precursor is brought into contact with the carbon-Nafion layer, and the resulting solution is sprayed on a glassy carbon disc, electrodeposited using the pulsed electrochemical deposition (PED) technique. The advantage of this method is that it activates not only the interface of the electrode surface but also the layer in its full depth. Electron micrographs and X-ray diffraction (XRD) characterization verified the nanocrystalline shape of the $\mathrm{Pt}$ particles. For comparison, Pt nanoparticles were also deposited by the constant current technique. Among the $\mathrm{Pt}$ precursors used, hexachloroplatinic acid $\left(\mathrm{H}_{2} \mathrm{PtCl}_{6}\right)$ precursor was turned out to be the most suitable for this preparation technique. The results showed an increased catalytic activity towards methanol oxidation for the PED Pt nanoparticles. The same group extended their work to the synthesis of $\mathrm{Pt}-\mathrm{Ru}$ catalysts with varying $\mathrm{Ru}$ content, i.e., from 10-60 at \%. The Pt-Ru catalyst with 50 at. \% Ru was identified to be the most active for methanol oxidation due to the oxophilic nature associated with the addition of $\mathrm{Ru}$ [34]. Since then, numerous efforts have been made to develop the Pt-Ru catalysts towards improving the performance of the methanol oxidation in DMFCs. Figure 1 summarises the overall progress made so far in the development of Pt-Ru catalysts using electrodeposition for application in DMFCs.

Realising the importance of bimetallic catalysts, a great deal of effort has been made towards developing Pt-M alloys ( $\mathrm{M}=\mathrm{Cu}, \mathrm{Co}, \mathrm{Fe}, \mathrm{Mo}, \mathrm{Ni}, \mathrm{Rh}, \mathrm{Sn}$ ) via electrodeposition as anode catalysts in DLFCs. The primary aim of the bimetallic catalyst development was to improve the $\mathrm{CO}$ tolerance, which blocks the catalyst surface rendering it less active during the anodic oxidation of organic molecules in DLFCs. Table 2 compares the anodic oxidation of DLFCs over Pt/C and Pt-M/C catalysts. 


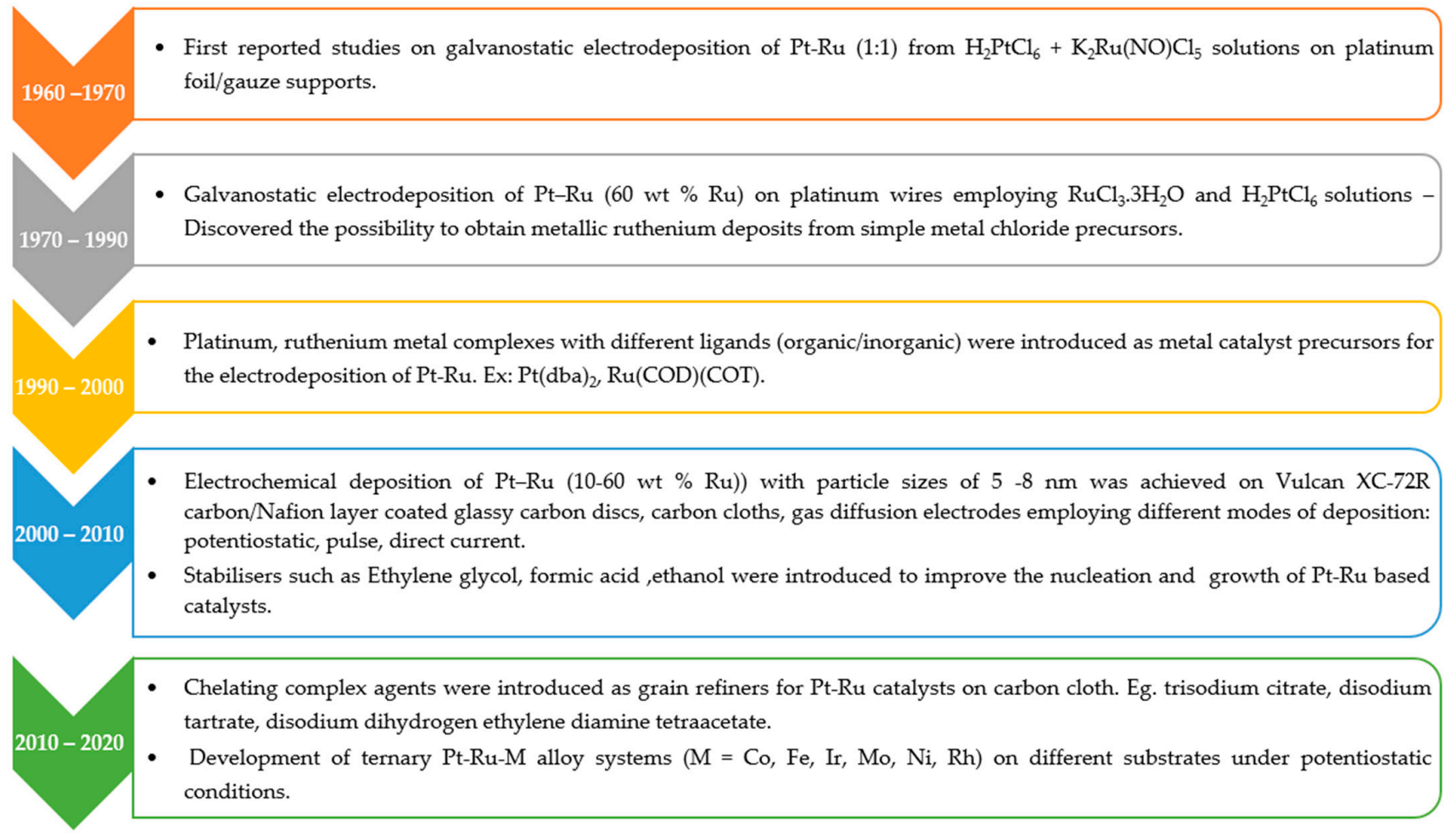

Figure 1. A summary of the progress in development associated with Pt-Ru catalysts utilising electrodeposition. Pt(dba) $)_{2}$ - Bis(dibenzylideneacetone)platinum; $\mathrm{Ru}(\mathrm{COD})(\mathrm{COT})$ —organometallic Ru precursor; COD-1,5-cyclooctadiene; COT =1,3,5-cyclooctatriene [35,36].

Table 2. A comparison of the anodic oxidation of DLFCs employing $\mathrm{Pt} / \mathrm{C}$ and $\mathrm{Pt}-\mathrm{M} / \mathrm{C}$ catalysts.

\begin{tabular}{|c|c|c|c|}
\hline Type of DLFC & $\mathrm{Pt} / \mathrm{C}$ & $\mathrm{Pt}^{\mathrm{P}} \mathrm{M}^{1} / \mathrm{C}$ & Reference \\
\hline \multirow{5}{*}{$\mathrm{DMFC}^{2}$} & $\mathrm{Pt}+\mathrm{CH}_{3} \mathrm{OH} \rightarrow \mathrm{Pt}_{3}-\mathrm{CH}_{2} \mathrm{OH}+\mathrm{H}^{+}+\mathrm{e}^{-}$ & $\mathrm{Pt}+\mathrm{CH}_{3} \mathrm{OH} \rightarrow \mathrm{Pt}-\mathrm{CO}+4 \mathrm{H}^{+}+4 \mathrm{e}^{-}$ & \multirow{5}{*}{ [37] } \\
\hline & $\mathrm{Pt}_{3}-\mathrm{CH}_{2} \mathrm{OH}+\mathrm{H}^{+}+\mathrm{e}^{-} \rightarrow \mathrm{Pt}-\mathrm{CO}+2 \mathrm{Pt}+3 \mathrm{H}^{+}+3 \mathrm{e}^{-}$ & $\mathrm{M}+\mathrm{H}_{2} \mathrm{O} \rightarrow \mathrm{M}-\mathrm{OH}+\mathrm{H}^{+}+\mathrm{e}^{-}$ & \\
\hline & $\mathrm{Pt}+\mathrm{H}_{2} \mathrm{O} \rightarrow \mathrm{Pt}-\mathrm{OH}+\mathrm{H}^{+}+\mathrm{e}^{-}$ & $\mathrm{Pt}-\mathrm{CO}+\mathrm{M}-\mathrm{OH} \rightarrow \mathrm{Pt}+\mathrm{M}+\mathrm{CO}_{2}+\mathrm{H}^{+}+\mathrm{e}^{-}$ & \\
\hline & $\mathrm{Pt}-\mathrm{CO}+\mathrm{Pt}-\mathrm{OH} \rightarrow \mathrm{Pt}-\mathrm{COOH}+\mathrm{Pt}$ & & \\
\hline & $\mathrm{Pt}-\mathrm{COOH} \rightarrow \mathrm{Pt}+\mathrm{CO}_{2}+\mathrm{H}^{+}+\mathrm{e}^{-}$ & & \\
\hline \multirow{6}{*}{$\mathrm{DEFC}^{2}$} & $\mathrm{CH}_{3} \mathrm{CH}_{2} \mathrm{OH} \rightarrow \mathrm{CH}_{3}-\mathrm{CHO}+2 \mathrm{H}^{+}+2 \mathrm{e}^{-}$ & $\mathrm{CH}_{3} \mathrm{CH}_{2} \mathrm{OH} \rightarrow \mathrm{CH}_{3}-\mathrm{CHO}+2 \mathrm{H}^{+}+2 \mathrm{e}^{-}$ & \multirow{6}{*}[38,39]{} \\
\hline & $\mathrm{Pt}+\mathrm{CH}_{3} \mathrm{CHO} \rightarrow \mathrm{Pt}-\left(\mathrm{CO}_{-} \mathrm{CH}_{3}\right)+\mathrm{H}^{+}+\mathrm{e}^{-}$ & $\mathrm{Pt}+\mathrm{CH}_{3} \mathrm{CHO} \rightarrow \mathrm{Pt}-\left(\mathrm{CO}-\mathrm{CH}_{3}\right)+\mathrm{H}^{+}+\mathrm{e}^{-}$ & \\
\hline & $\mathrm{Pt}-\left(\mathrm{CO}-\mathrm{CH}_{3}\right)+\mathrm{Pt} \rightarrow \mathrm{Pt}-\mathrm{CO}+\mathrm{Pt}-\mathrm{CH}_{3}$ & $\mathrm{Pt}-\left(\mathrm{CO}-\mathrm{CH}_{3}\right)+\mathrm{Pt} \rightarrow \mathrm{Pt}-\mathrm{CO}+\mathrm{Pt}-\mathrm{CH}_{3}$ & \\
\hline & $2 \mathrm{Pt}+\mathrm{H}_{2} \mathrm{O} \rightarrow \mathrm{Pt}-\mathrm{H}+\mathrm{Pt}-\mathrm{OH}$ & $2 \mathrm{M}+\mathrm{H}_{2} \mathrm{O} \rightarrow \mathrm{M}-\mathrm{H}+\mathrm{M}-\mathrm{OH}$ & \\
\hline & $\mathrm{Pt}-\mathrm{CH}_{3}+\mathrm{Pt}-\mathrm{H} \rightarrow 2 \mathrm{Pt}+\mathrm{CH}_{4}$ & $\mathrm{Pt}-\mathrm{CH}_{3}+\mathrm{Pt}-\mathrm{H} \rightarrow 2 \mathrm{Pt}+\mathrm{CH}_{4}$ & \\
\hline & $\mathrm{Pt}-\mathrm{CO}+\mathrm{Pt}-\mathrm{OH} \rightarrow \mathrm{Pt}+\mathrm{CO}_{2}+\mathrm{H}^{+}+\mathrm{e}^{-}$ & $\mathrm{Pt}-\mathrm{CO}+\mathrm{M}-\mathrm{OH} \rightarrow \mathrm{Pt}+\mathrm{CO}_{2}+\mathrm{H}^{+}+\mathrm{e}^{-}$ & \\
\hline \multirow{3}{*}{ DFAFC $^{2}$} & $\mathrm{HCOOH}+\mathrm{Pt} \rightarrow \mathrm{Pt}-\mathrm{CO}+2 \mathrm{H}^{+}+2 \mathrm{e}^{-}$ & $\mathrm{HCOOH}+\mathrm{Pt} \rightarrow \mathrm{Pt}-\mathrm{CO}+2 \mathrm{H}^{+}+2 \mathrm{e}^{-}$ & \multirow{3}{*}{ [40] } \\
\hline & $\mathrm{Pt}+\mathrm{H}_{2} \mathrm{O} \rightarrow \mathrm{Pt}-\mathrm{OH}+\mathrm{H}^{+}+\mathrm{e}^{-}$ & $\mathrm{M}+\mathrm{H}_{2} \mathrm{O} \rightarrow \mathrm{M}-\mathrm{OH}+\mathrm{H}^{+}+\mathrm{e}^{-}$ & \\
\hline & $\mathrm{Pt}-\mathrm{CO}+\mathrm{Pt}-\mathrm{OH} \rightarrow 2 \mathrm{Pt}+\mathrm{CO}_{2}$ & $\mathrm{Pt}-\mathrm{CO}+\mathrm{M}-\mathrm{OH} \rightarrow \mathrm{Pt}+\mathrm{M}+\mathrm{CO}_{2}$ & \\
\hline
\end{tabular}

However, the stability of carbon supported Pt-M bimetallic catalyst is reported to be affected over time owing to the second metal $(\mathrm{M}=\mathrm{Ru}, \mathrm{Sn}, \mathrm{Fe}, \mathrm{Ni})$ dissolution processes and corrosion of carbon support. Under DLFC operating conditions, secondary alloying metal (M) dissolution takes place, leading to a crossover of dissolved $\mathrm{M}^{\mathrm{n}+}$ species to the cathode, thereby inhibiting the ORR kinetics, besides membrane deterioration. To improve the stability and durability of the carbon supported Pt-M bimetallic catalysts, these are often alloyed with ternary metals such as Fe, Co, Ni [41]. 


\subsection{Palladium-A Possible Alternative to Platinum}

DMFCs are regarded as one of the promising candidates among the low temperature DLFCs due to their relatively low fuel cost and high energy density. However, the fuel crossover through the Nafion membrane is considered to be the major obstacle affecting the performance of the DMFC despite the development of Pt-based bimetallic catalysts. In order to accelerate the cathodic reaction rate, Pd-based catalysts are identified as a potential alternative due to their reduced cost, properties similar to Pt. In addition, Pd-based catalysts exhibit superior methanol tolerance in acidic DMFCs with increased activity. Formic acid electrooxidation is an essential anodic reaction that has been shown to be much more active than $\mathrm{Pt}$ when catalysed by Pd. Prior studies revealed that the electrocatalytic oxidation of formic acid is structure sensitive, suggesting that it can be affected mainly by the facets exposed on the surface of a catalyst [22,40,42]. Considering the importance of $\mathrm{Pd}$ as an important noble metal, this section focuses on its utilization as a methanol tolerant ORR catalyst, electrocatalytic oxidation of formic acid, organic molecules [40,43-45].

Zhang et al. [46] reported fabrication of Pd catalyst on graphite rods employing different procedures: (i) direct electrodeposition (DE), (ii) direct electrodeposition with Nafion coating (DENC), (iii) repeated electrodeposition with Nafion coating (RENC), and (iv) dip coating (DC) and a schematic representation is shown in Figure 2.

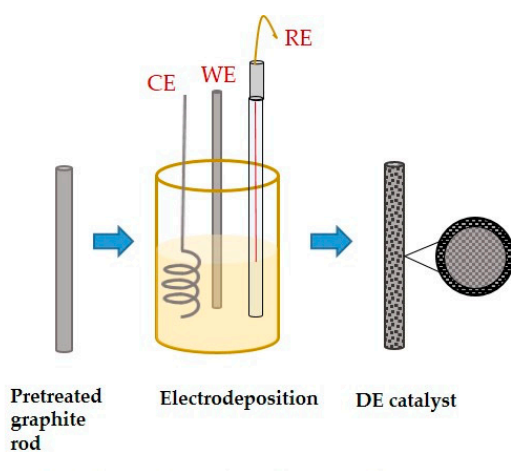

(a) Direct Electrodeposition (DE)

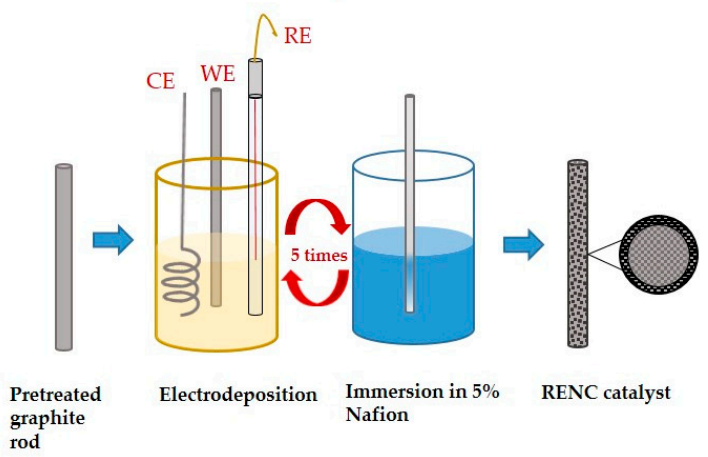

(c) Repeated Electrodeposition with Nafion Coating (RENC)

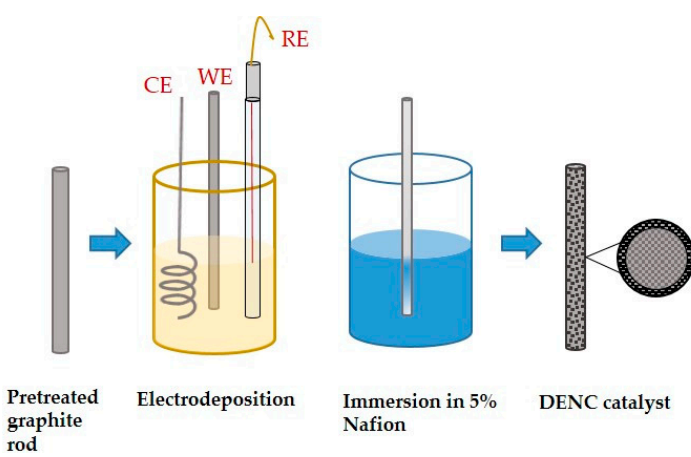

(b) Direct Electrodeposition with Nafion Coating (DENC)

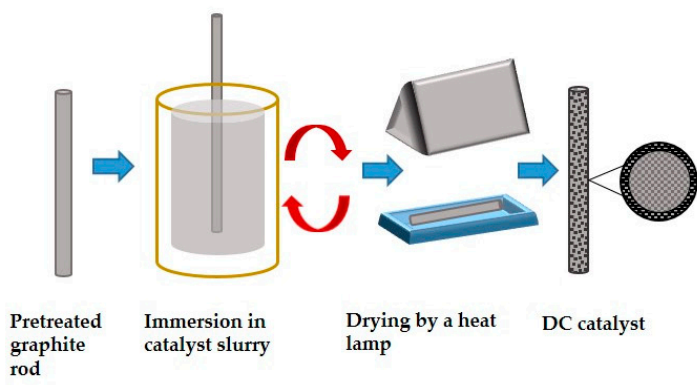

(d) Dip Coating (DC)

Figure 2. Schematic showing the procedure for fabricating the Pd catalyst on graphite rods through different routes: (a) Direct electrodeposition (DE), (b) Direct electrodeposition with Nafion coating (DENC), (c) Repeated electrodeposition with Nafion coating (RENC), and (d) Dip coating (DC) [46].

Graphite rods are considered as potential electrodes for microfluidic fuel cells due to their economic cost and inherent non-planar topologies. The graphite rods were initially pretreated to eliminate the surface oxides and impurities through a series of steps involving stirring in alkaline $(1 \mathrm{M} \mathrm{NaOH})$ and acidic $(1 \mathrm{M} \mathrm{HCl})$ media with an intermediate rinsing step followed by vacuum drying in an oven at $80 \mathrm{C}$, and $\mathrm{Pd}$ deposition employing the procedures shown in Figure 2. Microscopy characterisation results showed that the Pd catalysts synthesised by DE and DENC approach displayed a dendritic structure, but the ones prepared by RENC 
approach resulted in an island structure. Electrostatic repulsion between the $\left[\mathrm{PdCl}_{4}\right]^{2-}$ anions during electrodeposition and the anionic sulfonic groups of the membrane (Nafion) was shown to influence the morphological characteristics, changing it from dendritic to island. Cross sectional images showed that the electrodes prepared by DE/DENC had similar morphology with the same thickness, while the RENC based electrodes showed a multi-layer structure, highlighting the novel approach associated with the latter.

Electrochemical results showed superior formic acid oxidation performance, and durability of the RENC prepared Pd catalyst to the other fabrication methods. The multilayer structure of the RENC electrode and the presence of active Pd $\{111\}$ crystal facet was shown to produce a combined beneficial effect. It resulted in an increased electrochemical surface area with improved catalyst utilization, demonstrating the valuable features of RENC based approach.

\subsection{Alternative Carbon Supports}

High surface area carbon materials $\left(>1000 \mathrm{~m}^{2} \mathrm{~g}^{-1}\right)$ such as carbon nanotubes (CNTs) are used to improve the metal dispersion further. CNTs are nanostructured hexagonal rings and members of the fullerene family. They are formed from planar crystalline graphene sheets. CNTs are distinguished from other forms of carbon nanomaterials by their cylindrical shape. Because of their wide pore distribution, excellent chemical stability and surface area, good aspect ratio, and electrical conductivity, CNTs are regarded as the most commonly used catalyst support in fuel cells [24,25,47]. Metal particles deposited on CNT would be advantageous for a wide range of electro-catalytic applications. Despite their widespread use, CNTs are hydrophobic in nature that allows poor adsorption of catalyst precursors and catalysts. To get effective metal dispersion on support, surface modification without alteration in the properties of CNTs is essential. Therefore, they are subjected to functionalization treatment, through which oxygen-containing functional groups such as carbonyl $(-\mathrm{C}=\mathrm{O})$, hydroxyl $(-\mathrm{OH})$, carboxyl $(-\mathrm{COOH})$ are created on the CNTs surface so as to make it hydrophilic [48]. Surface modification of CNTs by functionalization (chemical/electrochemical) is essential for the control of noble metal nanoparticle size and dispersion without aggregation $[49,50]$.

Ye et al. [51] reported the synthesis of uniform Pt nanoclusters on the functionalized single walled nanotubes (SWCNTs) electrode using the pulse electrodeposition technique. For comparison, deposition was also carried out on the functionalized Vulcan carbon electrode. SEM images showed that the Pt/Vulcan exhibited long leaf-like nano clusters with a diameter of 200-300 nm. The Pt nanoclusters deposited on SWCNTs exhibited a flower-like morphology and were composed of leaf-like substructures of length $\sim 40 \mathrm{~nm}$ and diameter of 100-200 nm with a better dispersion than that of $\mathrm{Pt} /$ Vulcan. The results showed that changing the support material from Vulcan to SWCNTs influenced the nucleation and growth, size, morphology, and dispersion of the deposited Pt. Electrochemical results showed that $\mathrm{Pt} / \mathrm{SWCNT}$ displayed larger electrochemical surface areas, enhanced activities, and stabilities towards methanol oxidation and oxygen reduction than that of $\mathrm{Pt} /$ Vulcan. RDE results showed that ORR kinetics on Pt/SWCNTs followed a 4-electron pathway. The authors explained that the substructures of the Pt nanocluster, along with the unique structural and electrical properties, were the responsible factors for its enhancement in activity towards the methanol oxidation and ORR over that of Pt/Vulcan.

Zhao et al. [52] developed a novel three-step electrochemical method to deposit Pt-Ru$\mathrm{Ni}$ alloy nanoparticle clusters on multi-walled carbon nanotubes (MWCNTs) and investigated the electrocatalytic methanol oxidation reaction. Figure 3 represents the schematic of the step-wise synthesis of Pt-Ru-Ni catalysts via electrodeposition on electrochemically activated MWCNTs. The authors attributed the enhanced activity towards the electrocatalytic activity of methanol oxidation reaction to the improved $\mathrm{CO}$ tolerance, synergetic effect of bifunctional catalysts, and presence of oxygen functional groups on the electrochemically activated MWCNTs surface. 

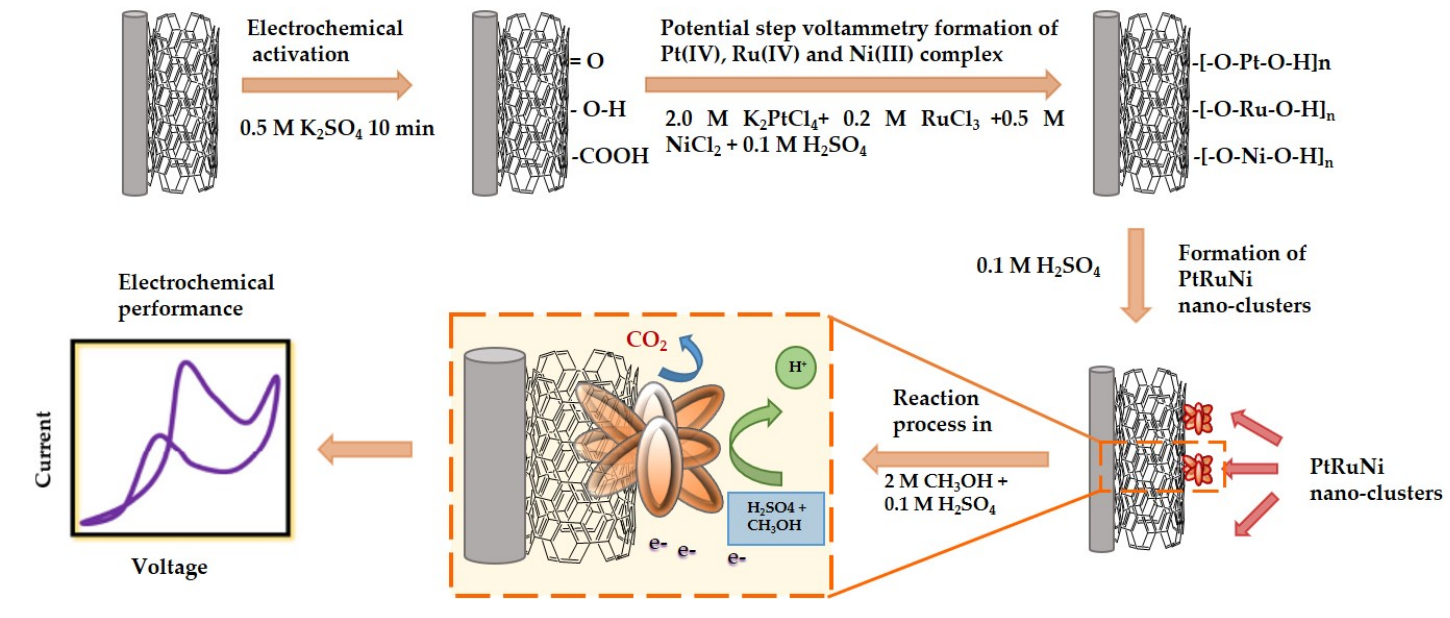

Figure 3. Schematic illustration of electrodeposition of PtRuNi on electrochemically activated MWCNTs and its enhanced catalytic performance towards methanol oxidation reaction [52].

Significant attention has been paid to the synthesis of CNTs based nanocomposites as support material for a considerable time because of their excellent chemical stability and electrical property. Moreover, other physiochemical and thermal properties of nanocomposites such as high specific surface area, dimensional stability were contributed by the CNTs and other high surface carbon support materials. Many reports [16,53] presented a general overview of the electrode structures, recently developed materials, with an emphasis on the application of catalyst supported on various carbon supports in DLFCs.

Challenges in the development of electrode structure, materials, catalyst, catalyst support, viz., carbon black, carbon nanotubes, carbon nanocoils, carbon nanofibers were discussed briefly. Moreover, some of the developments in novel catalyst support materials, viz., nano structured polypyrrole on carbon, polyaniline on carbon black, were also discussed. For more than a decade, graphene $(\mathrm{G})$ and its oxide have been considered as emerging catalyst supports because of their high surface area, superior electrical conductivity, with improved mechanical strength and elasticity. However, the problem with them is that they tend to irreversible agglomerate and restack to graphite. This affects the surface area and obstructs the dispersion of G-supported $\mathrm{Pt}(\mathrm{Pt} / \mathrm{G})$ particles in the catalyst ink, which is to be coated on the GDL. Lyophilization could be considered as one of the facile approaches to avoid irreversible aggregation of the graphene oxide (GO). The lyophilization process was introduced to prevent the restacking of these sheets during liquid water evaporation, which is a major problem in the conventional drying process. The advantage of using this approach is that it can avoid the accumulation of $\mathrm{Pt} / \mathrm{G}$ with more exposure of isolated Pt particles to the electrolytic solutions, which makes them superior in terms of catalytic activity.

The development of three-dimensional (3D) graphene architectures is believed to open up a new promising avenue for their application in low temperature DLFCs. Moreover, the monolithic nature of $3 \mathrm{D}$ graphene with interconnected pores combined with its high surface area makes it unique as electrode support with high corrosion resistance, superior electrical conductivity for fuel cell applications. Maiyalagan et al. [54] examined 3D graphene as electrode support for methanol oxidation for the first time, demonstrated its potential for fuel cell application. Three-dimensional graphene was initially synthesized using nickel foam, ethanol precursors employing chemical vapor deposition (CVD) technique. Pt nanoparticles on 3D graphene were synthesised by pulse electrodeposition, and the performance was compared with the Pt deposited on carbon fibre ( $\mathrm{CFs})$, a similar 3D structure support with high chemical stability and electrical conductivity, larger specific surface area, and better three-dimensional network structures [55]. Raman spectroscopy results showed that the 3D graphene possessed single layer and multi-layer domains without any disorders/defects, indicating its high quality. SEM and XRD results showed 
that $\mathrm{Pt} / 3 \mathrm{D}$ graphene displayed a well dispersed morphology and smaller particle size in comparison to $\mathrm{Pt} / \mathrm{CFs}$. Electrochemical results showed that $\mathrm{Pt} / 3 \mathrm{D}$ graphene exhibited higher methanol oxidation catalytic activity and stability. The authors attributed the enhancement in catalytic activity with $\mathrm{Pt} / 3 \mathrm{D}$ graphene catalyst to the uniqueness of the 3D graphene in terms of their geometry with monolithic architecture surface with efficient mass transport, electrical conductivity, and dense coating of smaller size Pt nanoparticles.

Hsieh et al. [56] synthesized GO sheets by Hummers method followed by dispersion in distilled water. The resulting suspension was filtered with carbon paper as the filter to separate the GO sheets. Synthesis of Pd clusters was carried out on the GO substrate using pulse electrodeposition technique using a Pd containing solution in $\mathrm{HCl}$ medium. SEM images showed the presence of well dispersed Pd on the substrate. They displayed two different morphologies: one is star shaped nano clusters, and the other is cubes, with star shaped nano clusters being more dominant. XRD results in Figure 4 reported by the authors displayed the characteristic peaks, i.e., $\{111\},\{200\},\{220\}$ and $\{311\})$, confirming the face centred cubic (fcc) pattern of Pd and its crystalline nature. The variation in the growth ratios of the faces $\{111\} /\{220\}$ and $\{200\} /\{220\}$ indicated that the growth is anisotropic, mostly favour the growth along $\{111\}$ direction.

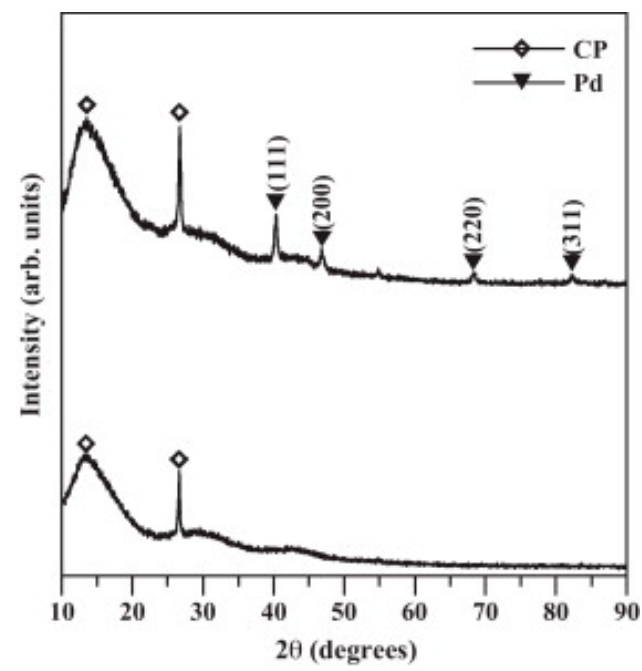

Figure 4. X-ray diffractograms of pure carbon paper and Pd deposited over GO-CP substrate. Reprinted with permission from [56].

The authors found that this anisotropic growth along the $\{111\}$ direction could be due to the specific anionic adsorption onto that face, resulting in the formation of more star shaped Pd nanoclusters. Graphene's multifunctional capabilities, such as promoting the dispersion of metallic Pd clusters, ionic diffusion, and charge transport, are considered to be responsible for the enhanced fuel oxidation performance.

\section{Electrodeposition on Non-Carbon Substrates}

Though $\mathrm{sp}^{3}$ bonded carbons such as Vulcan, CNT, carbon fibres, etc., possess good surface area with electronic conductivity, they are often prone to corrosion with an microstructural degradation during cyclic anodic polarization leading to an activity loss and catalyst particles detachment from the support [57-59]. Thus, the development of advanced and more stable supporting material remains to be of particular interest for improving the noble metal particle dispersion.

Stoychev et al. [60] explored the feasibility of depositing Pt on metallic and non-metallic electrodes such as tungsten, titanium, zirconium, rhenium, stainless steel, glassy carbon, and polyaniline. The studies revealed that tungsten, titanium, and glassy carbon were effective substrates for conducting preliminary nucleation and growth investigations for $\mathrm{Pt}$ deposition. Corduneanu et al. [61] synthesised Pd nanostructures at two different potentials 
and concentrations of palladium (II) sulphate $\left(\mathrm{PdSO}_{4}\right)$ solution on carbon substrates: highly oriented pyrolytic graphite and glassy carbon. The influence of the electrodeposition conditions on the topography of the carbon substrate and morphology of the deposited Pd were studied. The authors demonstrated that the electrodeposition conditions influenced the morphological characteristics and size distribution of the Pd nanostructures, and highlighted the potential applications of the Pd nanostructures in electrocatalysis and nanotechnology.

Noncarbon supports, such as metal oxides $\left(\mathrm{TiO}_{2}\right.$, Indium tin oxides) and Ti-nitrides (TiN) $[62,63]$, show better corrosion resistance and high melting points but are characterized by lower electrical conductivity. In addition, this group of support materials has a range of other advantages that carbon materials do not have. Few reviews [64,65] detailed research and development on several distinct classes of innovative support materials for DLFCs, including conductively doped diamonds, nanodiamonds, conductive oxides of tin, indium tin, titanium, tungsten, and carbides (tungsten carbides). The benefits, drawbacks, action mechanisms, and strategies to improve the electro-catalytic performance in terms of durability, stability were discussed briefly. Moreover, approaches to improve the current catalytic support materials were also discussed.

For instance, titanium-based support materials lead to higher $\mathrm{CO}$ tolerance than carbon support catalysts, but they are not used as often as carbon materials because their high molecular weight, which lowers the mass activity of the catalyst. These are being used when their advantages are more noteworthy than the disadvantages of their presence [66,67]. Mentus [68] reported the formation of noble metal $\mathrm{Pt} / \mathrm{TiO}_{2}$ and $\mathrm{Pd} / \mathrm{TiO}_{2}$ smooth bead arrays with well dispersion by multiple polarization of fresh $\mathrm{Ti}$ in aqueous solutions containing Pt, Pd using potentiodynamic deposition technique. Potentiodynamic deposition of noble metals such as $\mathrm{Pt}, \mathrm{Pd}, \mathrm{Au}$, and $\mathrm{Ag}$ on $\mathrm{Ti}$ surface to form metal/oxide layers is considered to be one of the most straightforward approaches to form metal/oxide layers. Electrodeposition of noble metals is generally motivated by the formation of $\mathrm{TiO}_{2}$. Titanium in aqueous solutions forms a stable $\mathrm{TiO}_{2}$, which acts as a self-template for the deposition of noble metals. The advantage of using this method is that $\mathrm{TiO}_{2}$ will prevent the agglomeration of nano particles by acting as a self-template which is believed to enhance the real surface area. The noble metal nanoparticles are reported to be distributed along the $\mathrm{TiO}_{2}$ surface under potentiodynamic conditions. At the initial stages of potential cycling, the growth of noble metal nanoparticles was shown to be favoured in relation to $\mathrm{TiO}_{2}$ growth. However, the increase in thickness of the so formed $\mathrm{TiO}_{2}$, with an increase in the number of polarization cycles, hindered the further formation of noble metal crystal nuclei. SEM images displayed the formation of noble metal smooth bead arrays with good dispersion. Electrochemical studies showed that the well dispersed arrays of $\mathrm{Pt}$ and $\mathrm{Pd}$ on $\mathrm{TiO}_{2}$ exhibited higher surface area, good characteristic features of metal surface electrochemistry, and comparable ORR activities with respect to the best $\mathrm{Pt}, \mathrm{Pd}$ catalysts synthesized by other methods. They proposed that these smooth metal bead arrays could be used as micro disc array electrodes. Fu et al. [69] reported on the synthesis and application of $\mathrm{Pd} /$ titania nanotubes/titanium $(\mathrm{Pd} / \mathrm{TNT} / \mathrm{Ti})$ by pulse electrodeposition for ORR in fuel cells. The authors studied the influence of synthesis conditions on the performance of $\mathrm{Pd} / \mathrm{TNT} / \mathrm{Ti}$ electrode in detail. The authors concluded that the $\mathrm{Pd} / \mathrm{TNT} / \mathrm{Ti}$, with better control of sensitization, activation conditions on the TNT/Ti surface before the Pd electrodeposition, will have an acceptable catalytic activity for ORR. They also reported that the pulse anodic current oxidation method is superior to the direct method for synthesising highly ordered and uniformly crystalline TNTs.

Another promising study of this kind of material is utilizing Ti meshes, which show good conductivity and are electrochemically stable and, therefore, can be good support for a wide range of electrocatalysts. Mesh-based anodes consist of only one layer, which allows the electrode to be thin. Additionally, electrodes based on meshes do not need to contain Teflon because they are more hydrophilic than conventional electrodes [70]. Chetty and his co-workers [70-73] investigated a range of $\mathrm{Pt}$ and $\mathrm{Pd}$ based catalyst coated on to a titanium mesh support prepared by electrodeposition from chloride precursors, for oxidizing a 
range of organic fuels, viz., formic acid, dimethoxymethane (DMM), trimethoxymethane (TMM), ethylene glycol, ethanol, and methanol. The results concluded that PtRu/Ti and $\mathrm{PtSn} / \mathrm{Ti}$ could be efficient catalysts for the oxidation of direct organic liquid fuels. Results from Figure 5 reported by Abraham et al. [71] demonstrated that the mesh-based electrodes could provide respectable power densities when direct liquid fuels are employed at near ambient temperatures.
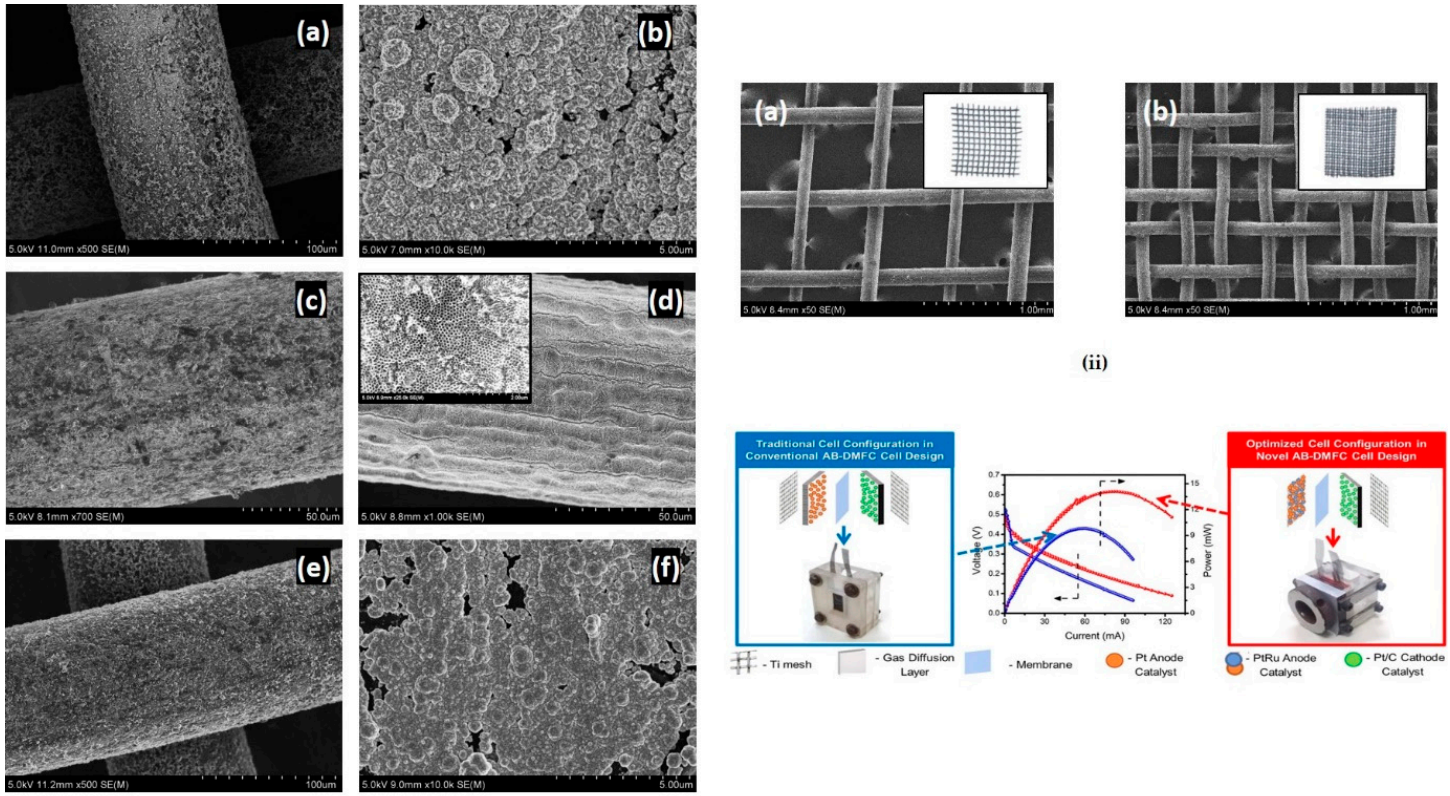

(i)

(iii)

Figure 5. (i) Scanning electron microscope images of Pt electrodeposited on Ti mesh at (a) low and (b) high magnification. Scanning electron microscope images of (c) pretreated Ti mesh and (d) TNT/Ti mesh with high magnification image in inset showing titania nanotubes. Scanning electron microscope images of PtRu (1:1) electrodeposited on Ti mesh at (e) low and (f) high magnification. (ii) SEM images for Ti mesh of (a) 40 mesh, and (b) 80 mesh size, with insets showing the corresponding photographs of the mesh. (iii) Figure showing the air-breathing direct methanol fuel cell (AB-DMFC) and its performance with $\mathrm{Pt}-\mathrm{Ru}$ catalyst deposited on Ti mesh with different configurations. Reprinted with permission from [71].

Similarly, TiN possess certain superior characteristics such as high electrical conductivity $\left(4000 \mathrm{~S} \mathrm{~cm}^{-1}\right)$, density $\left(5.1 \mathrm{~g} \mathrm{~cm}^{-3}\right)$ to carbon $\left(1190 \mathrm{~S} \mathrm{~cm}^{-1}, 1.9 \mathrm{~g} \mathrm{~cm}^{-3}\right)$, facilitates the formation of metal catalyst layer with low thickness, when supported on TiN offering low mass transfer limitations in contrast with carbon [74]. Considering this, one of the promising routes for developing new generation support is the investigation of $\mathrm{TiN}$ as a highly conductive specific surface area support for $\mathrm{Pt}, \mathrm{Pt}-\mathrm{Ru} / \mathrm{Sn}$ catalysts.

Indium tin oxide (ITO) is another kind of material that has good electronic conductivity and high optical transparency, widely used in areas such as an organic light emitting diode and photo voltaic devices. Kim et al. [75] studied the electrochemical deposition of Pd nanoparticles (NPs) on ITO substrates by varying the scan rate, and the number of cycles of potential scan using cyclic voltammetry (CV) technique and the activity towards formic acid oxidation was compared. The size and amount of the NPs deposited at a low scan rate, and high cycle number was shown to increase compared with the NPs deposited vice-versa (high scan rate, low cycle number). However, the electrochemical oxidation of formic acid results displayed that the performance of the latter was higher than that of the former. The authors concluded that large particle size of the NPs deposited at a low scan rate and high cycle number was responsible for its low activity. Table 3 shows the Pt and Pd-catalysts electrodeposited employing different modes of deposition on various non-carbon supports for applications in DLFCs involving other organic molecules as fuels. 
Table 3. Work reported on the electrodeposition of Pt and Pd on non-carbon supports.

\begin{tabular}{|c|c|c|c|c|c|c|c|c|}
\hline $\begin{array}{c}\text { Type of Fuel Cell } \\
\text { Reaction }\end{array}$ & Support & Catalyst & Technique & Electrolyte & Morphology & $\begin{array}{l}\text { Dominant } \\
\text { Facet }\end{array}$ & $\begin{array}{c}\text { Crystal Size, } \\
\mathrm{nm}\end{array}$ & Reference \\
\hline \multirow[b]{2}{*}{$\mathrm{MeOH}^{1}$ Oxidation } & $\mathrm{ITO}^{2}$ & $\mathrm{Pt}$ & $\mathrm{PS}^{3}$ & $5 \mathrm{mM} \mathrm{H}_{2} \mathrm{PtCl}_{6}+0.2 \mathrm{M} \mathrm{H}_{3} \mathrm{BO}_{3}$ & Spherical to sharp tip & $\{111\}$ & - & [76] \\
\hline & $\mathrm{ITO}^{2}$ & $\mathrm{Pt}-\mathrm{Ru}$ & PS $^{3}$ & $\begin{array}{c}5 \mathrm{mM} \mathrm{H}_{2} \mathrm{PtCl}_{6}+0.5 \mathrm{mM} \\
\mathrm{RuCl}_{3} \cdot 3 \mathrm{H}_{2} \mathrm{O}+0.2 \mathrm{M} \mathrm{H}_{3} \mathrm{BO}_{3}\end{array}$ & Spherical to sharp tip & $\{111\}$ & - & [76] \\
\hline $\mathrm{MeOH}^{1}$ Oxidation & $\mathrm{BDD}^{2}$ & $\mathrm{Pt}-\mathrm{Ru}$ & PS $^{3}$ & $\begin{array}{c}0.5 \mathrm{mM} \mathrm{H}_{2} \mathrm{PtCl}_{6}+0.5 \mathrm{mM} \\
\mathrm{RuCl}_{3}+0.5 \mathrm{M} \mathrm{H}_{2} \mathrm{SO}_{4}\end{array}$ & Rounded clusters & - & - & [77] \\
\hline \multirow{2}{*}{ EtOH ${ }^{1}$ Oxidation } & $\begin{array}{c}\text { Hydrogen } \\
\text { terminated BDD }\end{array}$ & $\mathrm{Pd}$ & PS $^{3}$ & $1 \mathrm{mM} \mathrm{PdCl}{ }_{2}+0.1 \mathrm{M} \mathrm{HCl}$ & Non-uniform particles & $\{111\}$ & 8.66 & [78] \\
\hline & $\begin{array}{c}\text { Hydrogen } \\
\text { terminated BDD }{ }^{2}\end{array}$ & Pd-Sn & $\mathrm{LSV}^{3}$ & $\begin{array}{c}0.26 \mathrm{M} \mathrm{C}_{2} \mathrm{H}_{6} \mathrm{O}_{6} \mathrm{~S}_{2} \mathrm{Sn}+ \\
1 \mathrm{M} \mathrm{CH}_{3} \mathrm{SO}_{3} \mathrm{H}^{4}\end{array}$ & Non-uniform particles & $\{111\}$ & 8.32 & [78] \\
\hline \multirow{2}{*}{ EtOH Oxidation } & $\begin{array}{l}\text { Oxygen terminated } \\
\mathrm{BDD}^{2}\end{array}$ & $\mathrm{Pd}$ & $\mathrm{PS}^{3}$ & $1 \mathrm{mM} \mathrm{PdCl}_{2}+0.1 \mathrm{M} \mathrm{HCl}$ & Non-uniform agglomerates & - & - & [79] \\
\hline & $\begin{array}{l}\text { Oxygen terminated } \\
\mathrm{BDD}^{2}\end{array}$ & $\mathrm{Pd}-\mathrm{Ni}$ & PS $^{3}$ & $\begin{array}{c}0.01 \mathrm{M}\left[\mathrm{Ni}\left(\mathrm{NO}_{3}\right)_{2} \cdot 6 \mathrm{H}_{2} \mathrm{O}\right] \text { in } \\
\text { acetate buffer }\end{array}$ & Non-uniform agglomerates & - & - & [79] \\
\hline \multirow{2}{*}{$\mathrm{MeOH}^{1}$ Oxidation } & $\mathrm{Ti}$ & Pt-Sn & $\mathrm{GSP}^{3}$ & $\begin{array}{c}2 \mathrm{mM} \mathrm{H}_{2} \mathrm{PtCl}_{6}+10 \mathrm{mM} \mathrm{SnCl}_{2} \\
+50 \mathrm{mM} \text { sodium citrate }+_{10 \mathrm{mM} \mathrm{H}_{2} \mathrm{SO}_{4}}\end{array}$ & $\begin{array}{l}\text { Uniform particles with } \\
\text { sharp features }\end{array}$ & $\{200\}$ & 12.3 & {$[80]$} \\
\hline & $\mathrm{Ti}$ & $\mathrm{Pt}-\mathrm{Ru}$ & $\mathrm{GSP}^{3}$ & $\begin{array}{c}2 \mathrm{mM} \mathrm{H}_{2} \mathrm{PtCl}_{6}+4 \mathrm{mM} \mathrm{SnCl}_{2}+ \\
50 \mathrm{mM} \text { sodium citrate }+ \\
10 \mathrm{mM} \mathrm{H}_{2} \mathrm{SO}_{4}\end{array}$ & $\begin{array}{l}\text { Uniform spherical } \\
\text { agglomerates }\end{array}$ & $\{200\}$ & 6 & [80] \\
\hline
\end{tabular}

${ }^{1} \mathrm{HCOOH}$ : Formic acid; MeOH: Methanol; EtOH: Ethanol; ${ }^{2}$ BDD: Boron doped diamond; ${ }^{3} \mathrm{CV}$ : Cyclic voltammetry; PS: Potentiostatic; SWP: Square wave potential; GS: Galvanostatic; GSP: Galvanostatic pulse; ${ }^{4} \mathrm{Pd}$ deposition followed by $\mathrm{Sn}$ deposition using stannous methanesulfonic acid $\left(\mathrm{C}_{2} \mathrm{H}_{6} \mathrm{O}_{6} \mathrm{~S}_{2} \mathrm{Sn}\right)$ and methane sulfonic acid $\left(\mathrm{CH}_{3} \mathrm{SO}_{3} \mathrm{H}\right)$. 


\section{Shape Control-A Way Forward}

The unique electronic structure of nanosized metal particles, as well as their exceptionally large surface areas, have generated interest in the use of nanostructured catalysts. Because electrochemical reactions are surface sensitive, this property is critical for a catalyst's effective functioning [81]. The electrodeposition of noble metals such as $\mathrm{Pt}, \mathrm{Pd}$, and also deposit properties, which differ widely depending on the substrate, are well recognised. However, Pt deposition from aqueous solutions typically results in large catalyst particles ranging in size from 50 to $90 \mathrm{~nm}$. To produce nanoparticles via electrodeposition, two fundamental modes of particle formation must be controlled: nucleation and growth. Nucleation is the intensity with which a stochastic arrangement of inbound atoms spontaneously arranges itself into a crystal, whilst the rate at which these nucleated zones spread outwards is referred to as growth. To form nanoparticles, growth must be controlled while nucleation is encouraged.

Ye et al. [82] worked on controlling the shape of Pt particles at desirable locations on Nafion-bonded carbon black substrates, through the introduction of shape control additives: poly ethylene glycol (PEG-10000), lead (II) acetate during pulse electrodeposition. Comparison of the morphological results evidenced the role of additives in obtaining shapes such as clump-like crystal aggregations, elongated leaf-like structures with PEG10000 , lead (II) acetate in contrast to spherical clusters obtained without them. The study demonstrated an alternative to the conventional method of preparation and a novel strategy to enhance the utilization of the Pt catalyst and its electrochemical active surface area through the introduction of shape control additives. Li et al. [83] aimed at improving the ORR performance of the cathode by minimizing the Pt loading in the electrode. They introduced a new pulsed electrodeposition method that combines the coating of $\mathrm{Pt}$ seeds on a Nafion-bonded carbon substrate, with the particle size and shape regulated by the addition of poly ethylene glycol (PEG) to the deposition solution. Electrodeposited $\mathrm{Pt}$ cathode catalyst, prepared by the coating of Pt seeds and PEG addition, was shown to perform better than the electrode prepared using commercial $\mathrm{Pt} / \mathrm{C}$ catalyst. The authors discussed the possible reasons highlighting the beneficial effects of Pt seeds and PEG on the increased activity of prepared Pt cathode catalysts. They concluded that introducing PEG into the deposition solution would decrease the $\mathrm{Pt} / \mathrm{C}$ particle size with controllable crystallite morphology and the adoption of the methodology would be very useful in the design and fabrication of fuel cell electrodes.

Various Pt-based and Pd-based nano-architectures such as nanorods, nanowires, nanocubes, nanoplates, three-dimensional flower-shaped nanoparticles (nanoflowers), etc. have recently emerged as convincing nanomaterials for electrocatalysis due to their porous nature, large surface area, and more active centres. Few studies [84-86] presented a facile electrochemical approach to synthesize Pt nanflowers, Pd nanoplates arrays (NPAs) onto the glassy carbon, gold substrate through surfactant assisted cyclic potential scan, tested towards methanol oxidation. According to the studies, the electrode coated with NPAs exhibited a large active surface area and good catalytic activity and stability. To further explore the process, the same group synthesised Pd nanomaterials with varied morphologies on gold substrates using specially adapted surfactant-assisted cyclic potential scanning technique using various surfactants. The researchers concluded that this method provides an effective technique to deposit highly catalytic Pd nanoparticles, additional nanostructured noble metals such as $\mathrm{Pt}, \mathrm{Rh}$, and $\mathrm{Au}$, and that it can be broadened to the formation of their binary alloys with high catalytic activity directly on the substrate.

Another facile approach is to reduce the as synthesized GO on carbon cloth electrode (CCE), commercially available support (also known as GDL) used in fuel cells, followed by its potentiostatic reduction, and synthesise $\mathrm{Pt}$ using electrodeposition. The advantages of this approach are, it is a facile, economic, large scale, and eco-friendly method. It involves a single step reduction process that forms a thin and flexible structure with more winkles on the CCE, which may provide more perfect sites for the deposition of noble metal nanoparticles. Yao et al. [87] developed this approach to synthesise Pt nanoflowers 
on reduced graphene oxide (RGO)/CCE by potentiostatic electrodeposition. Firstly, an aqueous solution of GO was coated on the CCE, followed by single step potentiostatic reduction of GO. Then the deposition was carried out on the RGO/CCE substrate using $3 \mathrm{mM} \mathrm{H}_{2} \mathrm{PtCl}_{6}$ in $0.5 \mathrm{M} \mathrm{H}_{2} \mathrm{SO}_{4}$ for Pt nanoflowers and $3 \mathrm{mM} \mathrm{H}_{2} \mathrm{PtCl}_{6}$ in $0.1 \mathrm{M} \mathrm{KCl}$ for Pt nanoparticles. For comparison, deposition was carried out on bare CCE without RGO. X-ray photoelectron spectroscopy (XPS) results showed a dominant increase in $\mathrm{C}=\mathrm{C}$ surface functional groups and declined oxygenated groups on reducing GO. SEM images showed the formation of winkles, confirming the presence of RGO. Pt/CCE and Pt/RGO/CCE displayed a flower-like morphology when deposited in an acidic medium. On the other hand, they displayed spherical morphology when deposited in an alkaline medium. In both cases, Pt/RGO/CCE showed better dispersion and uniformity. Electrochemical studies showed that Pt catalysts deposited on RGO/CCE exhibit higher electrochemical surface areas and electro-catalytic activities towards the oxidation of methanol, formic acid with improved stability than that of the Pt catalysts deposited on bare CCE. The reason for their enhancement in activities is due to the well dispersion of $\mathrm{Pt}$ on RGO/CCE and easier organic molecule penetration through its surface.

Luo et al. [88] studied the activity of facet-dependent bimetallic $\mathrm{CoPt}_{3}$ catalysts for the oxidation of methanol. In order to create shape-controlled nanoparticles, growth was regulated, while controlling the nucleation. During the nucleation stage, an excessive amount of precursor is typically consumed, hampering the further growth of the metal alloy $\left(\mathrm{CoPt}_{3}\right)$. To circumvent this, a non-injection method was employed to synthesise spherical, cubical, and flower-like nanocrystals with selective facets by injecting the precursors into the reaction mixture under hot temperature condition for rapid nucleation with slow crystal growth. By altering the oleylamine (OLA) to oleic acid (OA) ratio in the presence of benzyl ether, a non-coordination solvent, the nucleation and growth rates were partially adjusted. Physical characterization results revealed that the cubic crystals exhibited smaller sizes with $\{100\}$ dominant faces while the flower-like crystals resulted in larger size with $\{111\}$ face as the predominant ones. Comparison of the electrochemical test results demonstrated the dual role played by flower-like crystals in facilitating the $\mathrm{CO}$ removal and improving the electrooxidation of methanol.

Recent advances in the development of technologies for controlled synthesis of materials at the nanoscale have opened up new avenues for designing catalysts atom by atom. The complexity lies in determining how the engineering of a surface's structure should be directed toward desired catalytic functionality [89]. Engineering noble metals into porous nanoparticles (NPs) is considered to be an excellent way of enhancing catalytic performance through the generation of more active high index facets [90].

Shape controlled noble metal (Pt, Pd) nanocrystals enclosed by high index facets are known to primarily impact the unexceptional activity and stability enhancement towards reactions such as organic molecule oxidations, ORR, etc. However, it is challenging to synthesize the high index faceted nanocrystals owing to their high surface energy. Tian et al. [91,92] developed a programmed direct electrodeposition procedure to synthesize Pt, Pd tetrahexahedral (THH) nano crystals bounded by $\{730\}$ high index facets. Pt nanoparticles previously electrodeposited on GC substrate were subjected to a square wave potential step. TEM images showed that the synthesized THH nanocrystals are bounded by 24 high index faces. Electrochemical studies showed that $\mathrm{Pt}, \mathrm{Pd} \mathrm{THH}$ nanocrystals displayed exceptionally high activities towards ethanol oxidation with high stability. The authors demonstrated the potentiality of the square wave technique to synthesize noble metal nanocrystals with high index faces, whose shape can be reconstructed by varying either the potential limits of a square wave or by changing the precursor concentration.

Hsu et al. [93] demonstrated the feasibility of utilizing Pt nanoparticles efficiently by tailoring their shape on a tungsten carbide (WC) substrate via pulse electrodeposition and investigated the effect of particle shape on the electrochemical performance of the methanol oxidation reaction. The deposition potential had a considerable influence on particle shape, with the formation of cubic, dendritic particles at $0.14 \mathrm{~V}, 0.04 \mathrm{~V}$ vs. NHE (normal hydrogen 
electrode). Cu stripping voltammetry results showed that the preferential orientation for cubic particles is mostly $\{100\}$ whereas, for dendrites, the orientation is along $\{111\}$ direction. Electrochemical test data revealed that the Pt dendrites showed predominantly higher electrochemical performance towards methanol oxidation reaction than the cubic particles.

Though there were noteworthy advances made in the shape-controlled synthesis of noble metals, most of the extensive investigations included the development of $\mathrm{Pt}$, $\mathrm{Pd}$ nanostructures on ITO, $\mathrm{Au}, \mathrm{Si}$, and so on. Shape controlled noble metal $(\mathrm{Pt}, \mathrm{Pd})$ architectures were achieved via electrodeposition with or without stabilisers, surfactants, and templates. The development of template free noble metal crystals with various shapes, structures on carbon-based substrates would be beneficial for a variety of electro-catalytic applications besides fuel cells. Electrodeposition has the advantage of maintaining a high level of controllability since the electrode voltage or applied current is a useful parameter for influencing the structure of the metal synthesized. Deposition potential has a great influence on controlling the morphology of metal nanoparticles and is regarded critical for producing nanostructures by potentiostatic deposition. Controlling the surface structure of nanostructured metals using the deposition potential is a reliable approach to produce metal nanostructures with a preferred orientation, size, and shape. Because of the aforementioned advantages, electrochemical deposition methods have received a lot of attention in the synthesis of dendritic structures (which have a central stem from side branches). Furthermore, electrodepositing noble metal dendritic architectures will increase its electrochemical active surface area, making it more favourable and convenient for fuel cell applications.

Chetty and his group [94-99] addressed the challenge of obtaining palladium nanostructures on carbon based substrates without the need for a template/surfactant/structure directing agent. Dendritic Pd structures were synthesized on a carbon black (Vulcan) support coated on a graphite substrate using two different template free electrochemical techniques: cyclic voltammetry and constant voltage. The template/surfactant free methods developed by the group involved tuning of the morphology of palladium particles from spherical to dendritic structure, which is projected to eventually become the shape capture attribute of catalyst development for fuel cell applications. The methods developed demonstrated a new way of creating surface functional groups on the variety of carbon coated substrates (ranging from Vulcan mesoporous carbon, in-house wood apple carbon, to $2 \mathrm{D}$ graphene) through electrochemical activation. The insertion of such defects on the carbon surface favoured a good deposition, resulting in dendritic morphology with dominant $\{111\}$ facets, which facilitated the better performance of fuel cell reactions such as ORR, formic acid oxidation in low temperature (direct methanol and formic acid) fuel cells. The results showed that tailoring the insertion of defects on the carbon according to their morphological nature (planar, tubular) will influence the shape and structure of metal deposited. Moreover, the development of Pd structures on substrates coated with different carbon supports (graphene, wood apple carbon, carbon nanotubes, Vulcan) and varying morphologies (such as planar, microspheres, tubular, mesoporous, etc.), displayed 3-4-fold increase in electrocatalytic activity in comparison to conventional Pd deposit.

Prior technologies were limited to the deposition of noble metals on carbon black support with defects, which favoured deposition with 'spherical' morphology. For instance, Pt deposits on electrochemically activated carbon support developed by Martin et al. [100] resulted in spherical morphology in contrast to the dendritic morphology obtained with $\mathrm{Pd}$ deposits. Figure 6 shows the influence of electrochemical activation on tuning the morphology from spherical to dendritic and their performance towards electrochemical oxidation.

Figures 7 and 8 show the schematic of the methodologies involving the morphology transition from spherical to dendritic, its development, and validation on other carbon supports. Volga et al. [98] extended it further by performing Pt electrodeposition on carbon black-coated carbon paper under potentiostatic mode at three different applied potentials: $0.2 \mathrm{~V}, 0 \mathrm{~V}$, and $-0.2 \mathrm{~V}$ vs. SHE. Microscopy results evidenced the morphological transformation of the electrodeposited Pt from globular $(0.2 \mathrm{~V})$ to dendritic $(0 \mathrm{~V})$ and rosette- 
like $(-0.2 \mathrm{~V})$ structure, signifying the influence of deposition potential on the morphological characteristics. Subsequently, approaches were developed towards controlling the metal agglomerations that were formed at different conditions. For instance, Pd deposited at $0.5 \mathrm{~V}$ (vs. RHE) and above on carbon supports resulted in the formation of irregular agglomerates. Controlling the agglomerates was accomplished either by tailoring the current or voltage [98] or by changing the catalyst support [101], or by altering the viscosity of the electrolyte by the addition of a suitable additive.
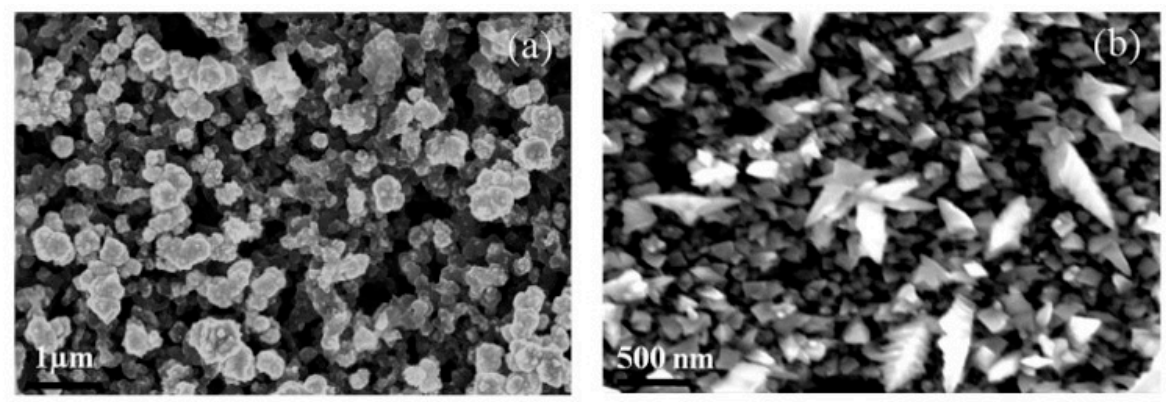

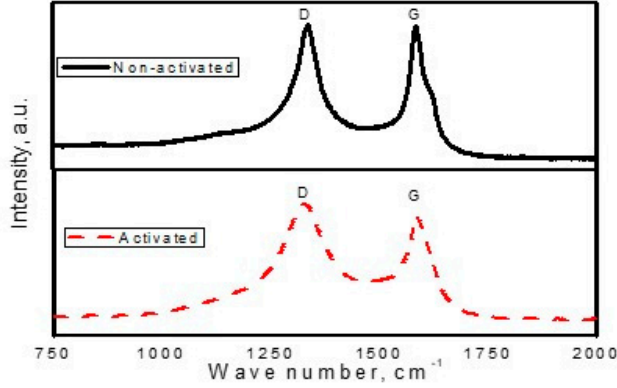

(c)

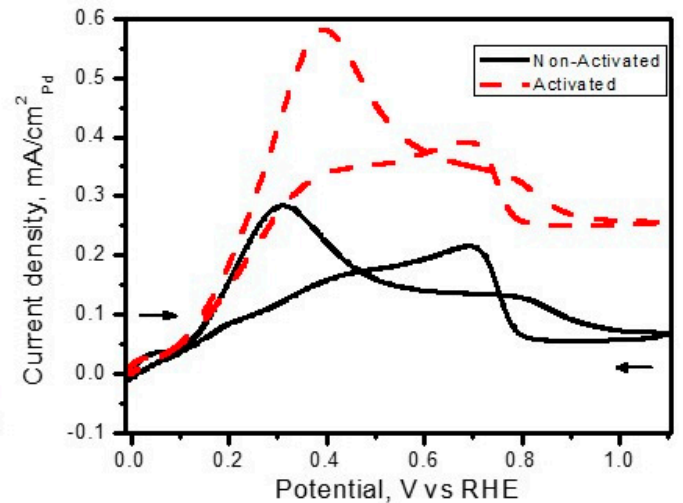

(d)

Figure 6. Scanning electron micrographs of Pd on (a) non-activated carbon support and (b) electrochemically activated carbon support. (c) Raman spectra of non-activated and electrochemically activated Vulcan coated on graphite electrode. Loading of Vulcan on graphite substrate: $100 \mu \mathrm{g} \mathrm{cm}^{-2}$. Number of electrochemical activation cycles: 100. (d) Cyclic voltammograms comparing the specific activity of Pd catalyst on non-activated carbon and electrochemically activated carbon in nitrogen saturated $0.5 \mathrm{M} \mathrm{H}_{2} \mathrm{SO}_{4}$ and $1 \mathrm{M} \mathrm{HCOOH}$ at a scan rate of $20 \mathrm{mV} \mathrm{s}^{-1}$ and room temperature. Reprinted with permission from [95].

For instance, in a work reported by Chetty and Maniam [102], a water soluble PEG was used as the additive, and the influence of PEG-6000 on the morphology of Pd deposited at $0.5 \mathrm{~V}$ (vs. RHE) was investigated. Physical characterisation data confirmed that the addition of PEG changed the Pd morphology from a spherical to a flower-like pattern, decreased the Pd intensity ratios between $\{111\} /\{220\}$ and $\{200\} /\{220\}$ planes, favoured the growth in a specific crystallographic direction with increase in PEG concentration up to $0.2 \mathrm{mM}$. Electrochemical tests evidenced a 3-4 times enhancement towards ORR, formic acid oxidation, achieved at the expense of reduced catalyst loading. For instance, at $50 \%$ catalyst loading, Pd nanoflowers demonstrated a 3-4-fold increase in electrochemical surface area, activity relative to spherical deposit $\left(83.4 \mathrm{~m}^{2} \mathrm{~g}^{-1} \mathrm{vs} .25 .1 \mathrm{~m}^{2} \mathrm{~g}^{-1}\right)$. 


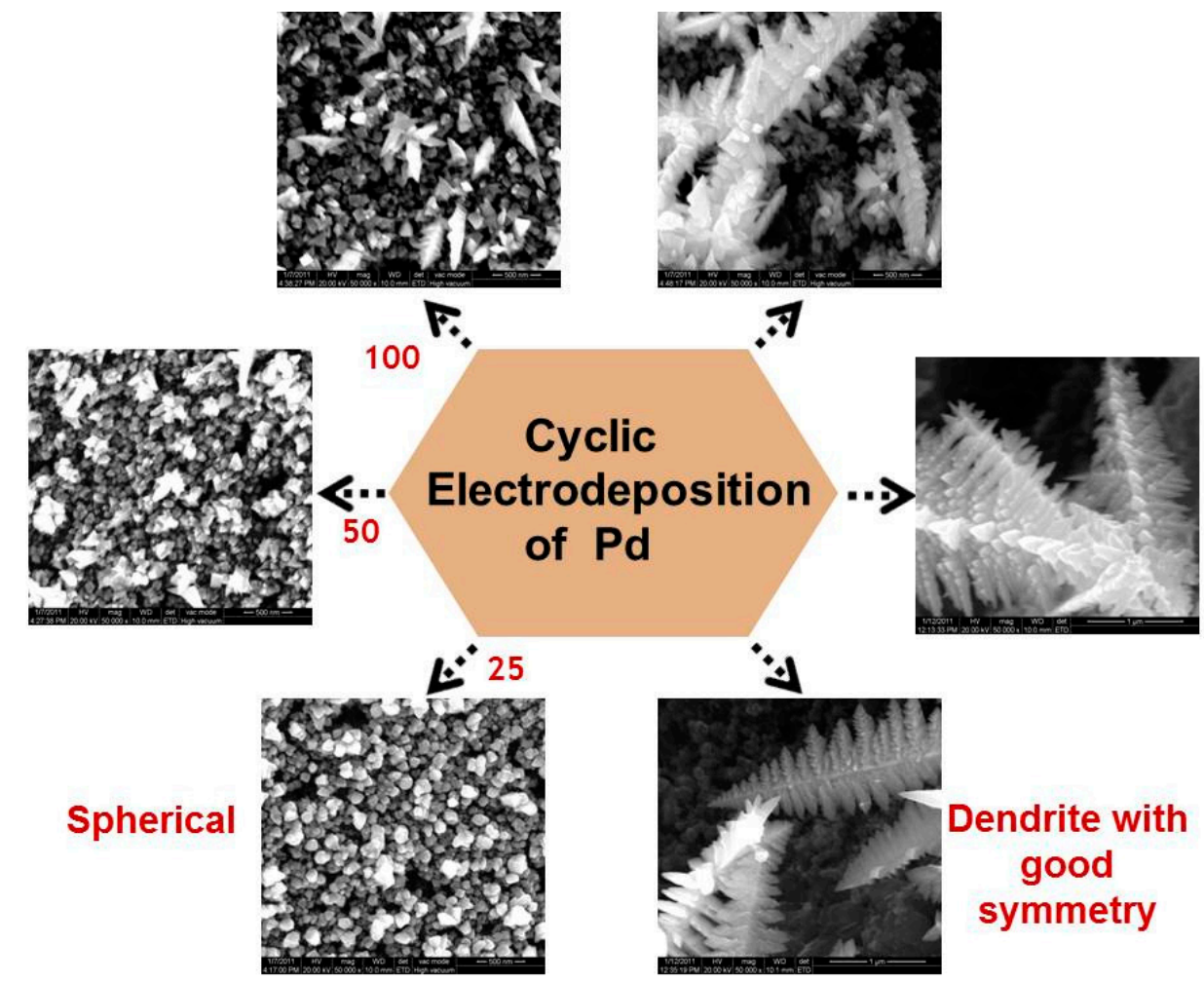

Figure 7. Scanning electron micrographs showing the morphological transitions of palladium supported on Vulcan. Reproduced with permission from [103].

With the growing interest in titania and the direct synthesis of titania nanotubes (TNT) as potential catalyst support electrocatalytic applications, Abraham et al. [96] synthesized Pd dendrites for oxidation of formic acid. TNTs with ordered symmetry and uniform distribution obtained by anodization of bare Ti in glycol-HF electrolyte were used as the catalyst support to synthesise Pd dendrites by a facile electrodeposition route. The authors evidenced the formation of Pd dendrites on anodized TNTs and reported an enhanced catalytic performance, signifying the dominant synergetic contribution from the TNT/Ti support. Moreover, Abraham and his co-workers [104] performed a detailed investigation to understand the role of electrochemical techniques and its related parameters on the morphological features of Pt deposited on Ti substrates, tested them to evaluate the oxidation of methanol. The study revealed that the Pt deposition on $\mathrm{Ti}$ is quite dependant on the waveform applied.

Pt deposited utilising the dynamic applied waveform electrodeposition techniques (cyclic voltammetry and pulse current deposition) resulted in more efficient, uniform $\mathrm{Pt}$ distribution on Ti relative to the constant ones (potentiostatic, galvanostatic deposition). Among the dynamic applied waveform electrodeposition conditions, $\mathrm{Pt}$ deposits obtained via the pulse electrodeposition technique was identified as the best choice of catalyst for methanol oxidation. The results of the investigations performed by the authors reflected the fundamental understanding of $\mathrm{Pt}$ depositions, their morphological characteristics at different modes of deposition (dynamic/constant waveform). Furthermore, it underlined the importance of using an ideal deposition technique and parameters to enable effective metal deposition from its metal $(\mathrm{Pt})$ precursor. Table 4 summarises the recent developments associated with the $\mathrm{Pt}$ and $\mathrm{Pd}$ electrodeposition for oxidation of methanol, ethanol, and formic acid at laboratory scale. 
Table 4. Electrodeposition of Pt and Pd on different support employed for the oxidation of organic molecules in three electrode electrochemical cells.

\begin{tabular}{|c|c|c|c|c|c|c|c|c|}
\hline $\begin{array}{c}\text { Type of Fuel Cell } \\
\text { Reaction }\end{array}$ & Support & Catalyst & Technique & Electrolyte & Morphology & $\begin{array}{l}\text { Dominant } \\
\text { Facet }\end{array}$ & $\begin{array}{c}\text { Crystal Size, } \\
\text { nm }\end{array}$ & Reference \\
\hline $\begin{array}{l}\mathrm{HCOOH}^{1} / \mathrm{EtOH} \\
\text { Oxidation }\end{array}$ & Carbon paper & Pt-Pd & $\mathrm{SWP}^{2}$ & $\begin{array}{l}1.2 \mathrm{mM} \mathrm{PdCl}_{2}+0.3 \mathrm{mM} \\
\mathrm{H}_{2} \mathrm{PtCl}_{6}+0.1 \mathrm{M} \mathrm{H}_{2} \mathrm{SO}_{4}\end{array}$ & Concave nanocubes & $\{610\}$ to $\{830\}$ & $28.7 \pm 5.4$ & [3] \\
\hline $\mathrm{MeOH}{ }^{1}$ Oxidation & $\mathrm{Ti}$ & Pt-Pd & $\mathrm{GSP}^{2}$ & $\begin{array}{c}2 \mathrm{mM} \mathrm{PdCl}_{2}+0.1 \mathrm{M} \mathrm{HClO}_{4} \\
2 \mathrm{mM} \mathrm{H}_{2} \mathrm{PtCl}_{6}+10 \mathrm{mM} \mathrm{H}_{2} \mathrm{SO}_{4}\end{array}$ & Nanoflower & $\{111\}$ & 7.8 & {$[80]$} \\
\hline HCOOH Oxidation & Anodised TNT/Ti & $\mathrm{Pd}$ & $\mathrm{CV}^{2}$ & $2 \mathrm{mM} \mathrm{PdCl}{ }_{2}+0.015 \mathrm{M} \mathrm{HClO}_{4}$ & Dendrites & $\{111\}$ & - & {$[96]$} \\
\hline HCOOH Oxidation & $\begin{array}{l}\text { Carbon coated } \\
\text { carbon paper }\end{array}$ & $\mathrm{Pt}$ & PS $^{2}$ & $2 \mathrm{mM} \mathrm{H}_{2} \mathrm{PtCl}_{6}+0.5 \mathrm{M} \mathrm{H}_{2} \mathrm{SO}_{4}$ & $\begin{array}{l}\text { Globular, dendritic, rosette } \\
\text { like }\end{array}$ & $\{111\}$ & $5.4,8,10.1$ & [98] \\
\hline EtOH Oxidation & Screen-printed gold & $\mathrm{Pd}-\mathrm{Ni}$ & $\mathrm{GS}^{2}$ & $\begin{array}{c}2.0 \mathrm{M} \mathrm{NH}_{4} \mathrm{Cl}+0.1 \mathrm{M} \\
\text { ethylenediamine }+0.2 \mathrm{M} \mathrm{NiCl}_{2} \\
+20 \mathrm{mM} \mathrm{PdCl}_{2}\end{array}$ & Tiny Globular & $\{111\}$ & - & [105] \\
\hline HCOOH Oxidation & Glassy carbon & Pd-Bi & $\mathrm{PS}^{2}$ & - & Planar & $\{110\}$ & 373.1 & [106] \\
\hline HCOOH Oxidation & Glassy carbon & $\mathrm{Pd}-\mathrm{Cd}$ & PS $^{2}$ & $\begin{array}{c}0.0005 \mathrm{M} \mathrm{PdCl}_{2}+0.001 \mathrm{M} \\
\mathrm{CdCl}_{2}+1 \mathrm{M} \mathrm{HCl}\end{array}$ & Cauliflower & $\{211\}$ & 113.6 & [106] \\
\hline \multirow{2}{*}{ MeOH Oxidation } & \multirow{2}{*}{$\begin{array}{l}\text { NiCo/Glassy } \\
\text { carbon }\end{array}$} & Pt-Ni & $\mathrm{CV}^{2}$ & $\begin{array}{l}1 \mathrm{mM} \mathrm{K}_{2} \mathrm{PtCl}_{4}+0.5 \mathrm{mM} \\
\mathrm{NiCl}_{2} \cdot 6 \mathrm{H}_{2} \mathrm{O}+0.1 \mathrm{M} \mathrm{KCl}\end{array}$ & Star & $\{220\}$ & - & [107] \\
\hline & & Pt-Co & $\mathrm{CV}^{2}$ & $\begin{array}{l}1 \mathrm{mM} \mathrm{K}_{2} \mathrm{PtCl}_{4}+0.5 \mathrm{mM} \\
\mathrm{CoCl}_{2} \cdot 6 \mathrm{H}_{2} \mathrm{O}+0.1 \mathrm{M} \mathrm{KCl}\end{array}$ & Coral reefs & $\{220\}$ & - & [107] \\
\hline
\end{tabular}

${ }^{1} \mathrm{HCOOH}$ : Formic acid; MeOH: Methanol; EtOH: Ethanol. ${ }^{2} \mathrm{CV}$ : Cyclic voltammetry; PS: Potentiostatic; SWP: Square wave potential; GS: Galvanostatic; GSP: Galvanostatic pulse. 

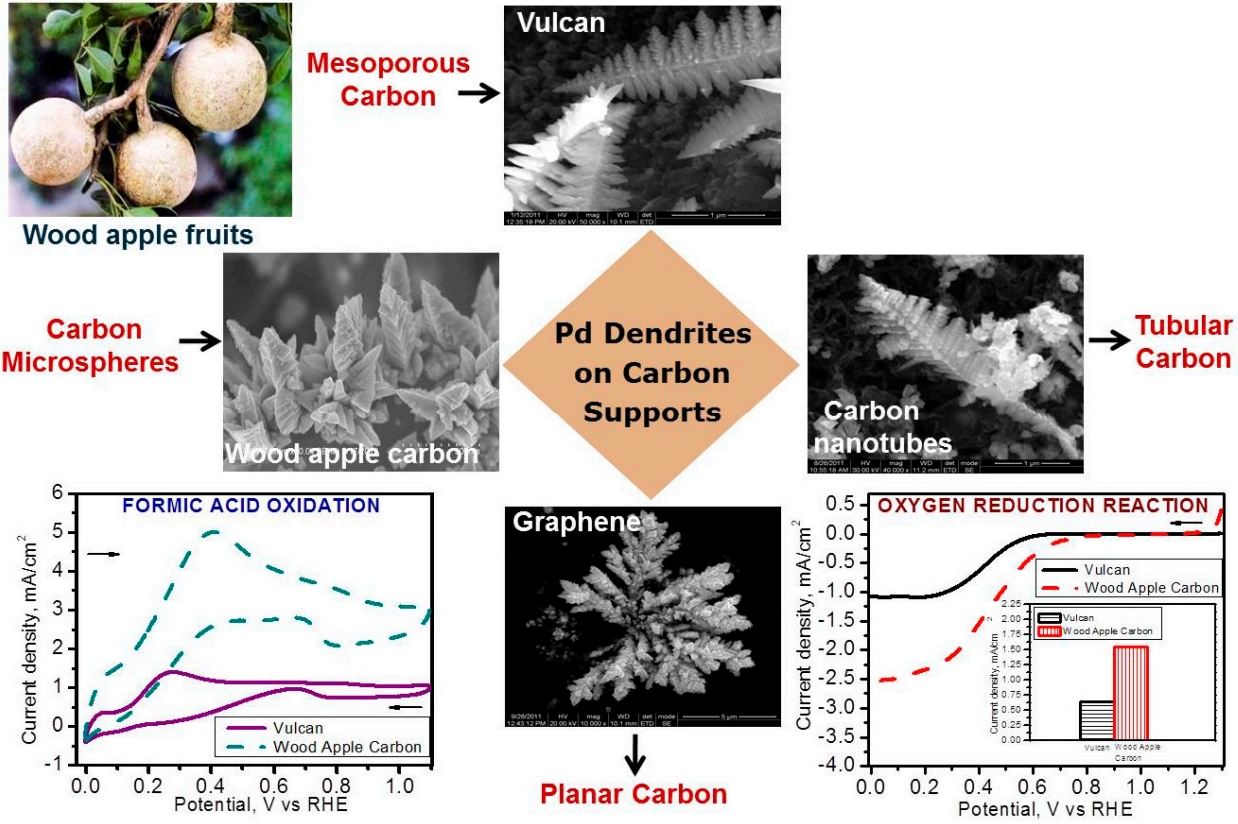

Figure 8. Universal strategy showing the palladium structures synthesised by template free cyclic voltammetric electrodeposition approach on different carbon supports and their formic acid oxidation, oxygen reduction reaction performance comparison. Reproduced with permission from [103].

\section{Deep Eutectic Solvents-A Versatile Approach}

Eutectic solvents are low toxic ecofriendly mixtures with exceptional characteristics such as wider electrochemical potential window, tunable physicochemical properties and biodegradable in nature. He et al. [108] attempted to electrodeposit Pd clusters utilizing ILs with 1-butyl-3-methyl imidazolium [BMIm] $]^{+}$as the cation and hexafluorophosphate $\left[\mathrm{PF}_{6}\right]^{-}$, tetrafluoroborate $\left[\mathrm{BF}_{4}\right]^{-}$as anions, and tested them for methanol oxidation. Threedimensional flower-shaped nanoparticles (nanoflowers) have recently emerged as convincing nanomaterial for electrocatalysis due to the presence of certain high-index metal crystal facets that are intrinsically more active to specific fuel cell reactions. The primary emphasis is focused on the synthesis of nanoflowers in non-aqueous systems such as ionic liquids (ILs), deep eutectic solvents [109]. Deep eutectic solvent (DES) is a simple eutectic based system that exhibits properties such as high conductivity, viscosity, surface tension, etc., similar to that of ionic liquids. Moreover, the advantages of DES in terms of non-toxicity, biodegradation, easy preparation at low cost, high purity make them fascinating in the template free synthesis of nanoflowers. Furthermore, DES involve a large amount of electroactive adsorption species that selectively adsorb on specific crystal faces via electrochemical adsorption, functioning as a structure mediating agent in the synthesis of shape-controlled nanocrystals.

Wei et al. [110] reported on the shape controlled electrochemical synthesis of Pt nanoflowers in DES using cyclic voltammetric deposition. The parameters such as precursor concentration, cycle number, scan rate, temperature were varied to tune the so formed Pt structures and regulate their growth. For comparison, $\mathrm{Pt}$ was also deposited using potentiostatic reduction of Pt precursor in DES. Cyclic voltammogram of Pt deposition on GC electrode in DES solution showed two peaks suggesting that Pt underwent a two-step reduction process. XPS results confirmed that the electrochemical reduction of Pt took place by two steps, i.e., from step (i) tetravalent state ( $\mathrm{Pt}(\mathrm{IV})$ ) to divalent ( $\mathrm{Pt}$ (II)) and step (ii) divalent (Pt (II)) to metallic state $(\mathrm{Pt}(0))$. SEM images reported by the authors showed the formation of Pt flowers with sharp petals, which varied according to precursor concentration, cycle number, scan rate, and room temperature. Electrochemical studies showed that the Pt nanoflowers with sharp petals synthesized by cyclic voltammetric deposition, using a high precursor concentration at a scan rate of $50 \mathrm{mV} \mathrm{s}^{-1}$ for 80 cycles exhibited higher electro-catalytic activity and stability than the nano structures synthesized by potentiostatic reduction and commercial catalyst 
towards ethanol oxidation. The formation of Pt nanoflowers was prominent when deposited at $80^{\circ} \mathrm{C}$. The decreased mass transportation of reactive species due to the high viscosity in DES hindered the formation of Pt flowers at lower precursor $\left(\mathrm{H}_{2} \mathrm{PtCl}_{6}\right)$ concentration. Increasing the number of cycles showed a transition from irregular quasi spherical particles to perfect flowers leading to the formation of aggregated flowers. Besides the cycle number, the scan rate also influenced the formation of flowers. A low scan rate resulted in the formation of rough nanosheets on the top of Pt nanostructures crystal surfaces, whereas increasing the scan rate to $50 \mathrm{mV} \mathrm{s}^{-1}$ resulted in the formation of Pt nanoflowers with sharp petals. Variation in the viscosities of DES with an increase in temperature influenced the morphology of Pt along with the other parameters. The superior capability of Pt nanoflowers with sharp petals to break the $\mathrm{C}-\mathrm{C}$ bond along with the oxidation of adsorbed $\mathrm{CO}$ was found to be responsible for the exceptional activities towards ethanol oxidation.

The same group [111] devised a simple electrodeposition route to achieve Pd polyhedral shaped nanocrystals with various sizes, including cubes, truncated cubes, cuboctahedrons, truncated octahedrons, and octahedrons with controlled size and shape. Pd nanocubes were initially synthesized from deep eutectic solvent $\mathrm{ChCl}$ :Urea by applying the square wave potential technique and controlling the Pd precursor concentration in the range $1 \mathrm{mM}$ to $5 \mathrm{mM}$, obtained well-controlled polyhedral nanocrystals with different intensity ratios of $\{100\}$ to $\{111\} \mathrm{Pd}$ facets on the surface. ChCl:Urea as a DES was observed to be critical in the development of different Pd polyhedral shaped crystals. Square wave potential technique was shown to favour the control of $\{111\} /\{100\}$ facets. Pd truncated cubes with an optimum $\{111\} /\{100\}$ facet ratio were identified to be the best one for formic acid oxidation, underlining the surface structure sensitive nature of the developed Pd polyhedrons. Their research highlighted the importance of rationale design and effective control over size and shape of the metal particles/crystallites for improving the performance in the electrocatalytic oxidation of formic acid. Table 5 provides a summary of the shape-controlled $\mathrm{Pt}$ and Pd catalysts that are obtained via electrodeposition employing ILs and DESs.

Table 5. Summary of the shape-controlled Pt and Pd catalysts that are obtained via electrodeposition employing ionic liquids and deep eutectic solvents.

\begin{tabular}{|c|c|c|c|c|c|c|c|}
\hline $\begin{array}{c}\text { Fuel Cell Reaction } \\
\text { Studied }\end{array}$ & Catalyst & Technique & Electrolyte & Morphology & $\begin{array}{c}\text { Dominant } \\
\text { Facet }\end{array}$ & $\begin{array}{c}\text { Crystal Size, } \\
\text { nm }\end{array}$ & Reference \\
\hline $\mathrm{MeOH}^{1}$ Oxidation & $\mathrm{Pt}$ & $\mathrm{PS}^{2}$ & $\begin{array}{c}\mathrm{H}_{2} \mathrm{PtCl}_{6}+ \\
{[\mathrm{BMIm}]\left[\mathrm{BF}_{4}\right]}\end{array}$ & nanoclusters & - & $<100$ & [108] \\
\hline MeOH Oxidation & $\mathrm{Pt}$ & PS & $\begin{array}{c}\mathrm{H}_{2} \mathrm{PtCl}_{6}+ \\
{\left[\mathrm{BMIm}_{[}\right]\left[\mathrm{PF}_{6}\right]}\end{array}$ & nanoclusters & - & $<100$ & [108] \\
\hline EtOH ${ }^{1}$ Oxidation & $\mathrm{Pt}$ & SWP & $\begin{array}{c}19.3 \mathrm{mM} \mathrm{H}_{2} \mathrm{PtCl}_{6}+ \\
\text { [ChCl:Urea-1:2] }\end{array}$ & $\begin{array}{c}\text { Concave tetra } \\
\text { hexahedral }\end{array}$ & $\{910\}$ & 167.5 & [110] \\
\hline $\mathrm{HCOOH}^{1}$ Oxidation & $\mathrm{Pd}$ & $\mathrm{SWP}^{2}$ & $\begin{array}{c}1 \mathrm{mM} \mathrm{PdCl}{ }_{2}+ \\
{[\mathrm{ChCl}: \text { Urea-1:2] }}\end{array}$ & Cube & $\{100\}$ & - & [111] \\
\hline HCOOH Oxidation & $\mathrm{Pd}$ & SWP & $\begin{array}{c}2 \mathrm{mM} \mathrm{PdCl} \mathrm{Pd}_{2}+ \\
{[\mathrm{ChCl}: \text { Urea-1:2] }}\end{array}$ & Truncated cube & $\{100\}$ & & [111] \\
\hline HCOOH Oxidation & $\mathrm{Pd}$ & SWP & $\begin{array}{c}3 \mathrm{mM} \mathrm{PdCl}{ }_{2}+ \\
{[\mathrm{ChCl}: U r e a-1: 2]}\end{array}$ & $\begin{array}{l}\text { Truncated } \\
\text { Octahedron }\end{array}$ & $\{100\},\{111\}$ & & [111] \\
\hline HCOOH Oxidation & $\mathrm{Pd}$ & SWP & $\begin{array}{c}4 \mathrm{mM} \mathrm{PdCl}_{2}+ \\
{[\mathrm{ChCl}: \text { Urea-1:2] }}\end{array}$ & $\begin{array}{l}\text { Truncated } \\
\text { Octahedron }\end{array}$ & $\{100\},\{111\}$ & & [111] \\
\hline HCOOH Oxidation & $\mathrm{Pd}$ & SWP & $\begin{array}{c}5 \mathrm{mM} \mathrm{PdCl} \\
{[\mathrm{ChCl}: U r e a-1: 2]}\end{array}$ & Octahedron & $\{111\}$ & & [111] \\
\hline EtOH Oxidation & $\mathrm{Pt}$ & $\mathrm{CV}^{2}$ & $\begin{array}{c}19.3 \mathrm{mM} \mathrm{H}_{2} \mathrm{PtCl}_{6}+ \\
\text { [ChCl:Urea-1:2] }\end{array}$ & Nanoflowers & $\{111\}$ & 200 & [112] \\
\hline EtOH Oxidation & $\mathrm{Pt}$ & SWP & $\begin{array}{c}19.3 \mathrm{mM} \mathrm{H}_{2} \mathrm{PtCl}_{6}+ \\
\text { [ChCl:Urea-1:2] }\end{array}$ & $\begin{array}{c}\text { Triambic } \\
\text { icosahedral }\end{array}$ & $\{771\}$ & 100 & [113] \\
\hline- & $\mathrm{Pd}$ & $\mathrm{CV}$ & $\begin{array}{l}10 \mathrm{mM} \mathrm{K}_{2} \mathrm{PdCl}_{4}+ \\
\text { [ChCl:Urea-1:2] }\end{array}$ & Nanoparticles & - & 20 & [114] \\
\hline
\end{tabular}


Table 5. Cont.

\begin{tabular}{|c|c|c|c|c|c|c|c|}
\hline $\begin{array}{c}\text { Fuel Cell Reaction } \\
\text { Studied }\end{array}$ & Catalyst & Technique & Electrolyte & Morphology & $\begin{array}{l}\text { Dominant } \\
\text { Facet }\end{array}$ & $\begin{array}{c}\text { Crystal Size, } \\
\text { nm }\end{array}$ & Reference \\
\hline EtOH Oxidation & $\mathrm{Pd}$ & SWP & $\begin{array}{c}1 \mathrm{mM} \mathrm{PdCl} \\
(\mathrm{ChCl}: U r e a-1: 2] \\
\end{array}$ & $\begin{array}{l}\text { Concave-disdyakis } \\
\text { triacontahedral }\end{array}$ & $\{631\}$ & - & [115] \\
\hline HCOOH Oxidation & $\mathrm{Pd}$ & $\mathrm{CV}$ & $\begin{array}{c}5 \mathrm{mM} \mathrm{PdCl} \\
{[\mathrm{ChCl}: \mathrm{EG}-1: 2]}\end{array}$ & Nanoparticles & - & $41 \pm 5$ & [116] \\
\hline HCOOH Oxidation & $\mathrm{Pd}$ & PS & $\begin{array}{c}6 \mathrm{mM} \mathrm{PdCl} \\
{[\mathrm{ChCl}: \mathrm{EG}-1: 2]}\end{array}$ & Nanoparticles & - & $41 \pm 5$ & [116] \\
\hline
\end{tabular}

${ }^{1} \mathrm{HCOOH}$ : Formic acid; MeOH: Methanol; EtOH: Ethanol; $\mathrm{ChCl}$ : Choline chloride; EG: Ethylene glycol. ${ }^{2} \mathrm{CV}$ : Cyclic voltammetry; PS: Potentiostatic; SWP: Square wave potential.

As can be seen from the table, it is clearly indicated that the DESs could be potential viable alternative electrolytes in obtaining shape-controlled Pt and Pd based catalysts. On the one hand, the wide electrochemical window allows deposition at high potentials and offers an advantage to maintain the stability of the electrolyte.

On the other hand, through tuning the viscosity of the IL/DES, it is possible to tailor the mass transportation of the species in the electrolyte, which dictates the shape and growth of the $\mathrm{Pt}$ and $\mathrm{Pd}$ during the electrochemical deposition. However, the major disadvantage with IL and DES is the requirement of high temperatures as certain IL with long cationic alkyl chain lengths such as hexyl, octyl based possess viscosities in the range of $9000 \mathrm{mPa}$ s [117]. Figure 9 provides an overall summary of the notable progress in the development of shape controlled Pt and Pd catalysts that have been achieved employing electrodeposition covering the period 2000-2020.

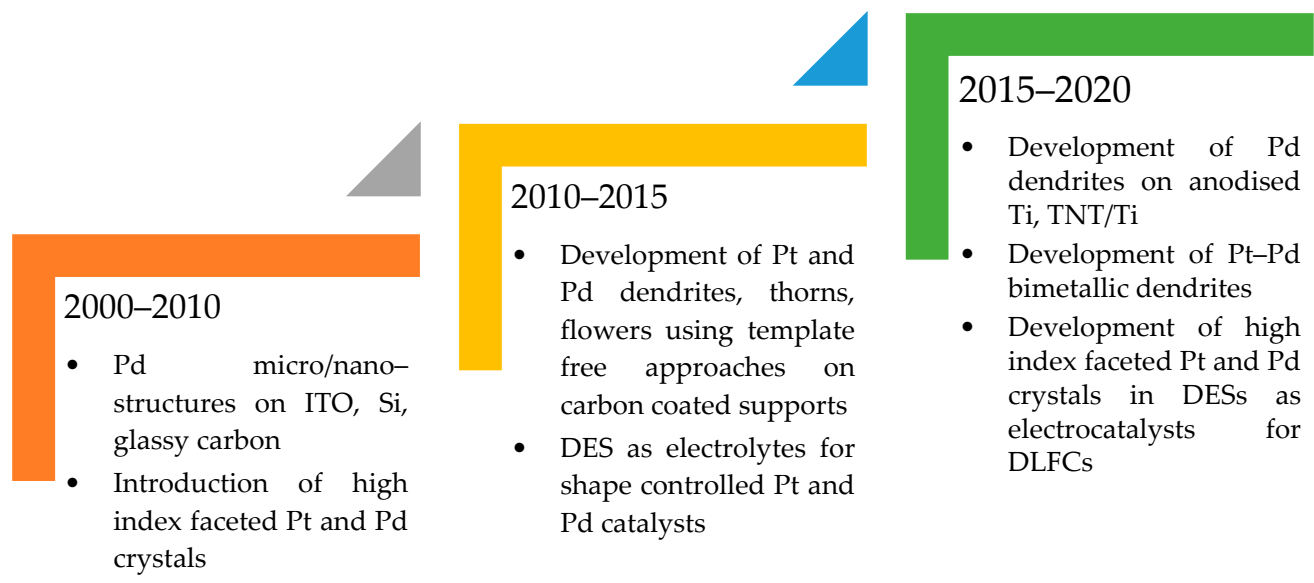

Figure 9. Progress in the developments of shape controlled noble metal $(\mathrm{Pt}, \mathrm{Pd})$ structures synthesised by electrodeposition covering the period 2000-2020.

While substantial attempts are being made to reduce the costs of the synthesis procedures, such as using low-cost solvents or relatively small amounts of ILs, DESs, or their combinations with water, the pricing still remains competitive. As a result, special attention should be paid to their use in large-scale industries. Furthermore, several commercially available ILs used as supporting electrolytes in the electrochemical deposition of $\mathrm{Pt}$ and $\mathrm{Pd}$ contain carcinogenic, hazardous, or toxic chemicals. (For example, $\left[\mathrm{BF}_{4}\right]^{-}$and $\left[\mathrm{PF}_{6}\right]^{-}$based ILs). To comply with EU regulations such as Registration, Evaluation, Authorisation, and Restriction of Chemicals (REACH), these substances might be required to be substituted with less hazardous ones such as sulfate-based ones.

\section{Fuel Cell Polarisation}

DLFCs are exceptionally attractive for low power and portable applications since they provide the convenience of fast recharging as well as a longer lifetime. However, there are 
various restrictions to the operational complexities of DLFCs, particularly with relation to cell design, in order to effectively replace the architecturally simpler batteries. Some of the obstacles impeding DLFC commercialization include an expensive electrocatalyst, liquid fuel crossover, and water management. One way of addressing these issues is to identify the best fuel delivery mode and develop an efficient fuel delivery system. Based on the fuel delivery mode, there are two basic types of DLFCs: passive and active [118,119]. An active system requires an external mechanism (such as pump, fan) to feed the fuel and oxidant.

On the contrary, the feeding mechanism for fuel and oxidant to the anode is passive and is generally accomplished through natural diffusion processes without the usage of any auxiliary devices. The passive DLFC derives its oxidant fuel from natural breathing of atmospheric air, hence the name passive or self-breathing DLFCs. In comparison to active DMFCs, self-breathing DMFCs with an open cathode have distinct advantages such as simple structure, small size, and light weight, as they do not require the employment of a sophisticated auxiliary equipment system. For stacks, active ones are favoured over passive ones for low-power portable applications (e.g., laptops).

For DLFCs to function effectively, they require ideal electrocatalysts with high activity in fuel oxidation and the oxygen reduction reaction for the anode and cathode, respectively. They should also have strong long-term stability, appropriate electrical conductivity, and a reasonable price. Although great efforts are being made around the world to develop novel electrocatalysts for fuel cells, most evaluations primarily discuss the findings of testing electrodeposited catalysts under the given operating conditions and pay minimal attention to real-time test results. There is a substantial amount of research in the literature devoted to the introduction of unique electrocatalytic systems that can be used as promising candidates for DLFCs. The majority of these experiments, however, are conducted in a typical three-electrode electrochemical cell. Likewise, the majority of the reviews that have been published so far have summarised the results based on the catalysts developed using wet chemical procedures.

This section will provide an overview of the performance of electrodeposited Pt and Pdbased electrocatalysts evaluated recently by different researchers in DLFCs. A Teflon coated microporous backing layer, Nafion-bonded catalyst, and a macroporous carbon-based gas diffusion layer (GDL) constitute the most typical DLFC anode electrode configuration. Volga et al. proposed a hybrid electrodeposition method for creating a bimetallic Pt-Ru catalyst based on carbon for methanol oxidation. Ru/C with different $\mathrm{Ru}$ wt \% (i.e., 8, 17, and $30 \mathrm{wt} \%$ ) was initially synthesised utilising the polyol procedure and ethylene glycol as a reducing agent. Electroreduction of $\mathrm{Pt}$ was performed by impregnating the Pt-precursor on $\mathrm{Ru} / \mathrm{C}$ coated carbon paper followed by square wave pulse deposition technique. The authors demonstrated that, when compared to the standard electroreduction method, their synthesis process could result in more uniform $\mathrm{Pt}$ particles with smaller size. The authors achieved a peak power density of $80 \mathrm{~mW} \mathrm{~cm}^{-2}$ when tested as an anode catalyst at $80{ }^{\circ} \mathrm{C}$ in a single DMFC with a $2 \mathrm{M}$ fuel concentration. The same authors extended it further and tested the oxidation performance of the electrodeposited $\mathrm{Pt}-\mathrm{Pd}$, nanoleafs employing formic acid as the liquid fuel [98,99].

However, in a passive mode of operation, this design inhibits the release of organic fuel oxidation products such as $\mathrm{CO}_{2}$ from the anode. This results in a noticeable change in mass-transport restrictions at the anode, resulting in fuel deficiency at the anode catalyst layer [120]. Recognizing the significance of mesh-based electrodes as viable and advantageous alternatives to standard GDLs, tests were carried out using various organic compounds as liquid fuels and metal mesh coated Pt-based catalysts as anodes. Metal meshes are substantially thinner and, in addition to operating as an effective current collector, can provide more efficient transportation of methanol to the catalyst layer and improve $\mathrm{CO}_{2}$ removal capabilities. Earlier studies demonstrated that the metal mesh electrodes enhanced fuel distribution and performance than the circular perforated current collectors [121]. Amongst the different mesh based electrodes such as stainless steel [122], gold plated stainless steel mesh [123], Ti mesh is identified as the potential substrate for the an- 
ode catalyst due to their superior physicochemical properties, stability, and good electrical conductivity than the others [72]. Moreover, Ti mesh was demonstrated to offer (i) good distribution of reactant (liquid organic fuels: methanol, ethanol, formic acid, etc.) to the catalyst layer, (ii) act as catalyst support, and (iii) a current collector. Such a configuration was proved to (i) improve the performance of self-breathing/passive DLFCs, (ii) effectively decrease the overall thickness of the MEA, and (iii) the corresponding losses associated with the resistances offered by the traditional ones [71,122-124].

Abraham et al. [71] designed a new clamping mechanism with reduced fuel leakage for a low temperature DMFC operating in an air-breathing mode (AB-DMFC) which limits cell resistance, tested them using $\mathrm{Pt}, \mathrm{Pt}-\mathrm{Ru}$ catalysts supported on Ti mesh synthesized by pulse electrodeposition. Multiple efforts were made to optimise the various Ti mesh-based MEA topologies for use in passive DMFCs. The single cell architecture was later extended to mini-stacks consisting of 2-cells, 6-cells, and the architecture built by Abraham et al. [71] is represented in Figure 10.

The 6-cell stack demonstrated an open circuit potential of $2.9 \mathrm{~V}$ when tested with $2 \mathrm{M}$ methanol and ambient air with a maximum power of $60 \mathrm{~mW}$, allowing it to operate a small portable device. Table 6 lists the summary of the fuel cell test results that are conducted using different conditions and liquid fuels.

\section{Conventional AB-DMFC Stack Architecture}

(a)
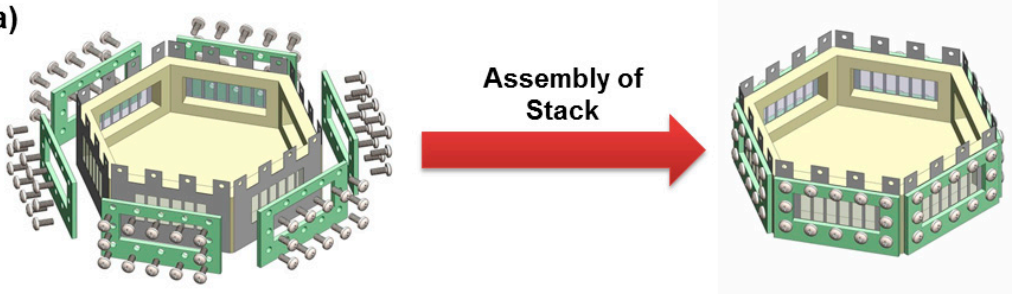

Novel AB-DMFC Stack Architecture
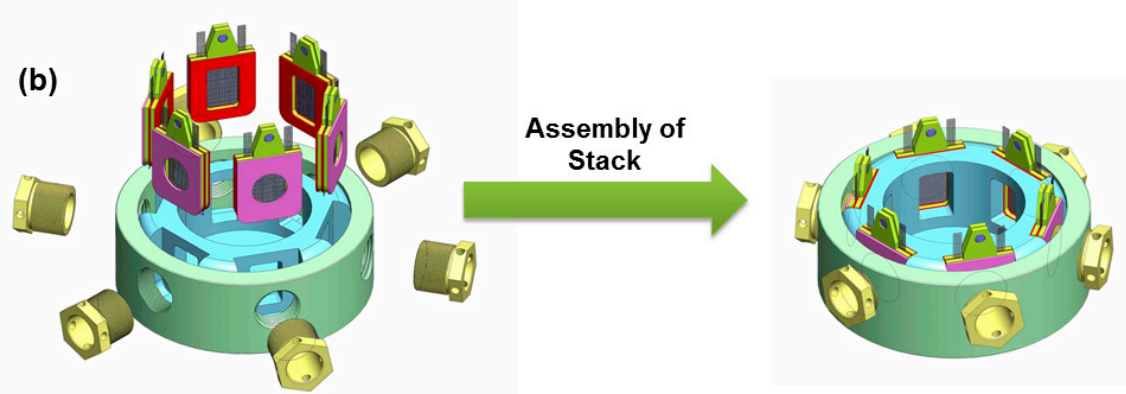

Figure 10. Comparison showing the fuel cell assembly of (a) conventional 6-cell DMFC stack (recreated from [122]), and (b) the novel 6-cell AB-DMFC architecture proposed by Abraham et al. Reprinted with permission from [71]. 
Table 6. Summary of the fuel cell tests conducted utilizing the electrodeposited catalysts with different liquid fuels: methanol and formic acid.

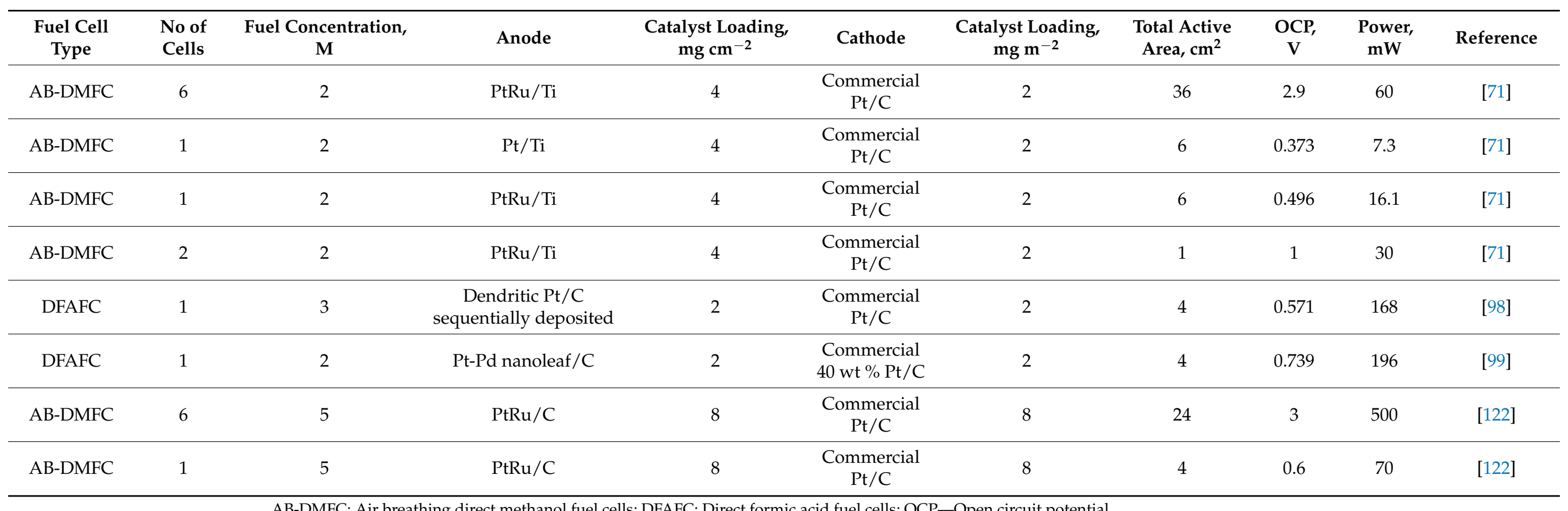




\section{Summary and Future Challenges}

The US DOE is currently deploying numerous fuel cells for specific uses [125]. Over the last decade, more than 10,000 fuel cell systems have been designed and installed. Several research works have been reported on the effect of catalyst synthesis, characterization (physical, chemical, electrochemical), and catalyst performance on the durability of direct liquid fuel cells. Furthermore, studies on the electrodeposition of $\mathrm{Pt}$, Pd catalysts for fuel cell applications have been carried out at laboratory scale and mostly in three electrode configuration involving half-cell studies. However, data on the real time fuel cell tests employing electrodeposited Pt, Pd-catalysts as anodes, methanol tolerant cathodes in DLFCs are scarce and very limited. Though there are certain key benefits with electrodeposition, one of the major issues is integrating the electrodeposited catalyst architecture as an MEA into the fuel cell, which drastically affects the fuel cell performance and its reliability.

A systematic integration of the MEAs involving electrodeposited catalyst is suggested to address the reliability challenge. There is still a gap in understanding the long-term durable characteristics of the shape-controlled Pt-based catalysts synthesized by electrodeposition. Investigations on scaling up the electrodeposition process for the synthesis of $\mathrm{Pt}$, Pd catalysts are minimal. Consequently, the technology readiness level (TRL) of the process continues to be at a low level. In contrast, other chemical synthesis processes reach the highest TRL, indicative of a commercially deployable process.

Therefore, it is essential that a criterion for scaling up the electrodeposition process with good fuel cell tests under real time conditions and life cycle analysis needs to be critically explored in future investigations. There is clearly a lack of data on the durability, electrochemical stability of the electrodeposited Pt and Pd-catalysts both at laboratory scale and real time operating conditions. Having understood the fact that electrochemical corrosion of carbon could primarily influence the performance, the durability of the catalysts, and transition to metal mesh electrodes would be a beneficial approach in the long term. While additive manufacturing techniques are rapidly pacing up, the development of metal mesh-based electrodes followed by electrochemical deposition of Pt and Pd-based catalysts is expected to make a significant impact on the cost reduction while achieving the targets set by the US DOE.

Few works on the application of DES such as Choline-based ones (Urea/EG) have been tested as suitable alternative electrolyte systems for obtaining shape controlled $\mathrm{Pt}$ and Pd electrodeposits ranging from cubes, flowers to octahedrons [111]. While the development of shape-controlled $\mathrm{Pt}$, Pd catalysts from electrochemical deposition processes is gaining attention, the strategy seeks substantial capital investments in order to perform electrochemical depositions at a scale spanning in the range of a few hundred litres of DES. The current market pricing status of ILs and DESs gives a clear indication that increasing their production at a larger scale will offer superior cost competitive benefits to the existing commercial supporting electrolytes, allowing for the possibility of achieving a price of about $\$ 1$ per kilogram of IL (or) DES [126].

Many of the works cited in this review focused on $\mathrm{Pt}, \mathrm{Pd}$, and their combinations as efficient electrocatalysts which are listed under the EU critical raw materials (CRM). It is also understood that, considering the predominance of critical or semi-critical material components present in DLFCs (such as Ti, for bipolar plates), and their economic relevance for EU markets, a number of scenarios should be devised to achieve acceptable CRM savings [127]. Controlling the Pt, Pd catalyst loading via the single step electrodeposition could meet the EU strategic objectives in achieving the CRM savings by at least $30 \%$ and contribute to the cost targets set by the US DOE.

\section{Conclusions}

The present review summarised the developments in the electrodeposition of $\mathrm{Pt}$ and Pd-based catalysts on carbon supports, non-carbon supports with conventional supporting electrolytes, ILs, and DESs as the potential supporting electrolytes. Electrodeposited Pt and Pd-based catalysts supported on various supports have shown to be very effective at 
improving the performance of electrochemical reactions in DLFCs, with Pt-based (Pt-Ru for methanol; Pt-Sn for ethanol) being predominant for direct alcohol-based fuel cells and Pd-based for direct formic acid fuel cells. Remarkable progress has been observed in producing shape-controlled $\mathrm{Pt}$, Pd-based catalysts via template free approach including programmed electrodeposition approach, utilizing IL and DES as the potential supporting electrolyte. While IL serves multiple functions in the electroreduction system, its ionic interactions and contributions to electrolyte stability require further investigation. The works cited demonstrate the scientific community's substantial efforts to develop efficient Pt and Pd-based electrodeposits on Ti, anodized Ti/TNTs, Ti meshes, stainless steel mesh, gold plated steel mesh, and perform real-time evaluations utilizing different liquid fuels.

With a better understanding of the advancements in the electrochemical deposition of $\mathrm{Pt}$ and Pd-based catalysts, electrodepositing metal catalysts with different shapes, structures on metal support could be a potential way forward for their commercialization. Substantial improvements in the durability of MEAs integrated with electrodes comprised of electrodeposited catalysts are desired to achieve the long-term strategic goals of US DOE targets. While significant progress has been made in understanding the features of $\mathrm{Pt}$ and Pd-based electrodepositions in various aqueous media, investigations involving DES as the electrolyte deserve detailed research. This review has outlined the major challenges to focus on at this point, which is intended to potentially benefit the research community working in this field and aid in the scale-up and rapid industrialization of electrodeposited catalysts for fuel cell applications.

Author Contributions: Conceptualization, All; methodology, K.K.M. and R.T.; resources, R.C. and K.K.M.; writing-K.K.M. and R.T.; writing-review and editing, R.C., S.P. and K.K.M.; supervision, R.C. and S.P. All authors have read and agreed to the published version of the manuscript.

Funding: This research has received funding from the European Union's Horizon 2020 research and innovation program under the Marie Sklodowska-Curie grant agreement No. 885793. A full fee waiver APC was granted for this article to be published in Applied Sciences.

Institutional Review Board Statement: Not applicable.

Informed Consent Statement: Not applicable.

Data Availability Statement: The data presented in this study are available upon request from the corresponding author.

Conflicts of Interest: The authors declare no conflict of interest.

\section{References}

1. Sun, C.; Negro, E.; Vezzù, K.; Pagot, G.; Cavinato, G.; Nale, A.; Herve Bang, Y.; Di Noto, V. Hybrid inorganic-organic protonconducting membranes based on SPEEK doped with WO3 nanoparticles for application in vanadium redox flow batteries. Electrochim. Acta 2019, 309, 311-325. [CrossRef]

2. Dunn, B.; Kamath, H.; Tarascon, J.-M. Electrical Energy Storage for the Grid: A Battery of Choices. Science 2011, 334, 928-935. [CrossRef] [PubMed]

3. Yu, Z.Y.; Huang, R.; Liu, J.; Luo, C.X.; Wang, C.Y.; Song, Q.T.; Xiao, C.; Yin, S.H.; Xu, B.; Sun, S.G. PdPt concave nanocubes directly electrodeposited on carbon paper as high active and durable catalysts for formic acid and ethanol oxidation. Electrochim. Acta 2020, 354, 136654. [CrossRef]

4. Gröger, O.; Gasteiger, H.A.; Suchsland, J.-P. Review-Electromobility: Batteries or Fuel Cells? J. Electrochem. Soc. 2015, 162, A2605-A2622. [CrossRef]

5. Ioroi, T.; Siroma, Z.; Yamazaki, S.I.; Yasuda, K. Electrocatalysts for PEM Fuel Cells. Adv. Energy Mater. 2019, 9, 1-20. [CrossRef]

6. Olabi, A.G.; Wilberforce, T.; Abdelkareem, M.A. Fuel cell application in the automotive industry and future perspective. Energy 2021, 214, 118955. [CrossRef]

7. Neaţu, Ş.; Neaţu, F.; Chirica, I.M.; Borbáth, I.; Tálas, E.; Tompos, A.; Somacescu, S.; Osiceanu, P.; Folgado, M.A.; Chaparro, A.M.; et al. Recent progress in electrocatalysts and electrodes for portable fuel cells. J. Mater. Chem. A 2021, 9, 17065-17128. [CrossRef]

8. Bernal Lopez, M.; Ustarroz, J. Electrodeposition of nanostructured catalysts for electrochemical energy conversion: Current trends and innovative strategies. Curr. Opin. Electrochem. 2021, 27, 100688. [CrossRef]

9. Kale, M.B.; Borse, R.A.; Gomaa Abdelkader Mohamed, A.; Wang, Y. Electrocatalysts by Electrodeposition: Recent Advances, Synthesis Methods, and Applications in Energy Conversion. Adv. Funct. Mater. 2021, 31, 1-24. [CrossRef] 
10. Google Patents. Available online: https://patents.google.com/patent/WO2014033756A2/en (accessed on 31 August 2021).

11. Fernández, J.L.; Walsh, D.A.; Bard, A.J. Thermodynamic Guidelines for the Design of Bimetallic Catalysts for Oxygen Electroreduction and Rapid Screening by Scanning Electrochemical Microscopy. M-Co (M: Pd, Ag, Au). J. Am. Chem. Soc. 2005, 127, 357-365. [CrossRef] [PubMed]

12. Durand, J.; Teuma, E.; Gómez, M. An Overview of Palladium Nanocatalysts: Surface and Molecular Reactivity. Eur. J. Inorg. Chem. 2008, 2008, 3577-3586. [CrossRef]

13. Shen, T.; Zhang, J.; Chen, K.; Deng, S.; Wang, D. Recent Progress of Palladium-Based Electrocatalysts for the Formic Acid Oxidation Reaction. Energy Fuels 2020, 34, 9137-9153. [CrossRef]

14. Antolini, E. Palladium in fuel cell catalysis. Energy Environ. Sci. 2009, 2, 915. [CrossRef]

15. Ojemaye, M.O.; Okoh, A.I. Global research direction on Pt and Pt based electro-catalysts for fuel cells application between 1990 and 2019: A bibliometric analysis. Int. J. Energy Res. 2021, 45, 15783-15796. [CrossRef]

16. Shaari, N.; Kamarudin, S.K.; Bahru, R.; Osman, S.H.; Md Ishak, N.A.I. Progress and challenges: Review for direct liquid fuel cell. Int. J. Energy Res. 2021, 45, 6644-6688. [CrossRef]

17. Viswanathan, B. Platinum-based anode catalyst systems for direct methanol fuel cells. In Direct Methanol Fuel Cell Technology; Elsevier: Amsterdam, The Netherlands, 2020; pp. 177-200.

18. Ding, C.; Dong, F.; Tang, Z. Research Progress on Catalysts for the Electrocatalytic Oxidation of Methanol. ChemistrySelect 2020, 5, 13318-13340. [CrossRef]

19. Zhao, X.; Liu, Q.; Li, Q.; Chen, L.; Mao, L.; Wang, H.; Chen, S. Two-dimensional electrocatalysts for alcohol oxidation: A critical review. Chem. Eng. J. 2020, 400, 125744. [CrossRef]

20. Li, Y.R.; Li, M.X.; Li, S.N.; Liu, Y.J.; Chen, J.; Wang, Y. A review of energy and environment electrocatalysis based on high-index faceted nanocrystals. Rare Met. 2021, 40, 3406-3441. [CrossRef]

21. Balakrishnan, P.; Dehghani Sanij, F.; Leung, P.; Su, H.; Xu, Q.; Zhao, T.S. Analyses and insights into 2D crystallite architected membrane electrode assemblies for polymer electrolyte fuel cells. Chem. Eng. J. 2021, 417, 129280. [CrossRef]

22. Folkman, S.J.; González-Cobos, J.; Giancola, S.; Sánchez-Molina, I.; Galán-Mascarós, J.R. Benchmarking Catalysts for Formic Acid/Formate Electrooxidation. Molecules 2021, 26, 4756. [CrossRef]

23. Ren, X.; Lv, Q.; Liu, L.; Liu, B.; Wang, Y.; Liu, A.; Wu, G. Current progress of Pt and Pt-based electrocatalysts used for fuel cells. Sustain. Energy Fuels 2020, 4, 15-30. [CrossRef]

24. Antolini, E. Carbon supports for low-temperature fuel cell catalysts. Appl. Catal. B Environ. 2009, 88, 1-24. [CrossRef]

25. Khodabakhshi, S.; Fulvio, P.F.; Andreoli, E. Carbon black reborn: Structure and chemistry for renewable energy harnessing. Carbon N. Y. 2020, 162, 604-649. [CrossRef]

26. Tominaka, S.; Momma, T.; Osaka, T. Electrodeposited Pd-Co catalyst for direct methanol fuel cell electrodes: Preparation and characterization. Electrochim. Acta 2008, 53, 4679-4686. [CrossRef]

27. Mohanty, A.; Garg, N.; Jin, R. A Universal Approach to the Synthesis of Noble Metal Nanodendrites and Their Catalytic Properties. Angew. Chemie Int. Ed. 2010, 49, 4962-4966. [CrossRef] [PubMed]

28. Gloaguen Electrocatalytic oxidation of methanol on platinum nanoparticles electrodeposited onto porous carbon substrates. $J$. Appl. Electrochem. 1997, 27, 1052-1060. [CrossRef]

29. Pozio, A.; De Francesco, M.; Cemmi, A.; Cardellini, F.; Giorgi, L. Comparison of high surface Pt/C catalysts by cyclic voltammetry. J. Power Sources 2002, 105, 13-19. [CrossRef]

30. Lee, K.; Zhang, J.; Wang, H.; Wilkinson, D.P. Progress in the synthesis of carbon nanotube- and nanofiber-supported Pt electrocatalysts for PEM fuel cell catalysis. J. Appl. Electrochem. 2006, 36, 507-522. [CrossRef]

31. Kim, H.; Subramanian, N.P.; Popov, B.N. Preparation of PEM fuel cell electrodes using pulse electrodeposition. J. Power Sources 2004, 138, 14-24. [CrossRef]

32. Wei, Z.D.; Chan, S.H.; Li, L.L.; Cai, H.F.; Xia, Z.T.; Sun, C.X. Electrodepositing Pt on a Nafion-bonded carbon electrode as a catalyzed electrode for oxygen reduction reaction. Electrochim. Acta 2005, 50, 2279-2287. [CrossRef]

33. Löffler, M.-S.; Groß, B.; Natter, H.; Hempelmann, R.; Krajewski, T.; Divisek, J. Synthesis and characterization of catalyst layers for direct methanol fuel cell applications. Phys. Chem. Chem. Phys. 2001, 3, 333-336. [CrossRef]

34. Löffler, M.-S.; Natter, H.; Hempelmann, R.; Wippermann, K. Preparation and characterisation of Pt-Ru model electrodes for the direct methanol fuel cell. Electrochim. Acta 2003, 48, 3047-3051. [CrossRef]

35. Tolmachev, Y.V.; Petrii, O.A. Pt-Ru electrocatalysts for fuel cells: Developments in the last decade. J. Solid State Electrochem. 2017, 21, 613-639. [CrossRef]

36. Sieben, J.M. Controlled size formation of electrodeposited Pt-Ru nanostructured catalysts using chelating compounds. Mater. Chem. Phys. 2011, 128, 243-249. [CrossRef]

37. Aricò, A.S.; Srinivasan, S.; Antonucci, V. DMFCs: From Fundamental Aspects to Technology Development. Fuel Cells 2001, 1, 133-161. [CrossRef]

38. Sánchez-Monreal, J.; García-Salaberri, P.A.; Vera, M. A mathematical model for direct ethanol fuel cells based on detailed ethanol electro-oxidation kinetics. Appl. Energy 2019, 251, 113264. [CrossRef]

39. Lamy, C.; Lima, A.; LeRhun, V.; Delime, F.; Coutanceau, C.; Léger, J.-M. Recent advances in the development of direct alcohol fuel cells (DAFC). J. Power Sources 2002, 105, 283-296. [CrossRef] 
40. Fang, Z.; Chen, W. Recent advances in formic acid electro-oxidation: From the fundamental mechanism to electrocatalysts. Nanoscale Adv. 2021, 3, 94-105. [CrossRef]

41. Kaur, A.; Kaur, G.; Singh, P.P.; Kaushal, S. Supported bimetallic nanoparticles as anode catalysts for direct methanol fuel cells: A review. Int. J. Hydrogen Energy 2021, 46, 15820-15849. [CrossRef]

42. Hoshi, N.; Kida, K.; Nakamura, M.; Nakada, M.; Osada, K. Structural Effects of Electrochemical Oxidation of Formic Acid on Single Crystal Electrodes of Palladium. J. Phys. Chem. B 2006, 110, 12480-12484. [CrossRef]

43. Karim, N.A.; Kamarudin, S.K. Introduction to direct alcohol fuel cells (DAFCs). In Direct Liquid Fuel Cells; Akay, R.G., Bayrakçeken, A.Y., Eds.; Elsevier: London, UK, 2021.

44. Hossain, S.S. Heteroatom-Doped Carbon Materials as Support for Anode Electrocatalysts for Direct Formic Acid Fuel Cells. Int. J. Electrochem. Sci. 2021, 16, 1-36. [CrossRef]

45. Han, S.; He, C.; Yun, Q.; Li, M.; Chen, W.; Cao, W.; Lu, Q. Pd-based intermetallic nanocrystals: From precise synthesis to electrocatalytic applications in fuel cells. Coord. Chem. Rev. 2021, 445, 214085. [CrossRef]

46. Zhang, B.; Ye, D.; Li, J.; Zhu, X.; Liao, Q. Electrodeposition of Pd catalyst layer on graphite rod electrodes for direct formic acid oxidation. J. Power Sources 2012, 214, 277-284. [CrossRef]

47. Basri, S.; Kamarudin, S.K.; Daud, W.R.W.; Yaakub, Z. Nanocatalyst for direct methanol fuel cell (DMFC). Int. J. Hydrogen Energy 2010, 35, 7957-7970. [CrossRef]

48. Komarova, N.S.; Krivenko, A.G.; Ryabenko, A.G.; Naumkin, A.V. Active forms of oxygen as agents for electrochemical functionalization of SWCNTs. Carbon N. Y. 2013, 53, 188-196. [CrossRef]

49. Guo, D.-J.; Li, H.-L. High dispersion and electrocatalytic properties of Pt nanoparticles on SWNT bundles. J. Electroanal. Chem. 2004, 573, 197-202. [CrossRef]

50. Mikolajczuk, A.; Borodzinski, A.; Stobinski, L.; Kedzierzawski, P.; Lesiak, B.; Kövér, L.; Tóth, J.; Lin, H.-M. Physicochemical characterization of the Pd/MWCNTs catalysts for fuel cell applications. Phys. Status Solidi 2010, 247, 3063-3067. [CrossRef]

51. Ye, F.; Wang, T.; Li, J.; Wang, Y.; Li, J.; Wang, X. Pt Nanoclusters Electrodeposited on Single-Walled Carbon Nanotubes for Electrochemical Catalysis. J. Electrochem. Soc. 2009, 156, B981. [CrossRef]

52. Zhao, Y.; Fan, L.; Ren, J.; Hong, B. Electrodeposition of Pt-Ru and Pt-Ru-Ni nanoclusters on multi-walled carbon nanotubes for direct methanol fuel cell. Int. J. Hydrogen Energy 2014, 39, 4544-4557. [CrossRef]

53. Zainoodin, A.M.; Kamarudin, S.K.; Daud, W.R.W. Electrode in direct methanol fuel cells. Int. J. Hydrogen Energy 2010, 35, 4606-4621. [CrossRef]

54. Maiyalagan, T.; Dong, X.; Chen, P.; Wang, X. Electrodeposited Pt on three-dimensional interconnected graphene as a free-standing electrode for fuel cell application. J. Mater. Chem. 2012, 22, 5286. [CrossRef]

55. Zhang, H.; Chen, N.; Sun, C.; Luo, X. Investigations on physicochemical properties and electrochemical performance of graphite felt and carbon felt for iron-chromium redox flow battery. Int. J. Energy Res. 2020, 44, 3839-3853. [CrossRef]

56. Hsieh, C.-T.; Liu, Y.-Y.; Roy, A.K. Pulse electrodeposited Pd nanoclusters on graphene-based electrodes for proton exchange membrane fuel cells. Electrochim. Acta 2012, 64, 205-210. [CrossRef]

57. Berenguer, R.; Marco-Lozar, J.P.; Quijada, C.; Cazorla-Amorós, D.; Morallón, E. Effect of electrochemical treatments on the surface chemistry of activated carbon. Carbon N. Y. 2009, 47, 1018-1027. [CrossRef]

58. Hung, C.-C.; Lim, P.-Y.; Chen, J.-R.; Shih, H.C. Corrosion of carbon support for PEM fuel cells by electrochemical quartz crystal microbalance. J. Power Sources 2011, 196, 140-146. [CrossRef]

59. Bayram, E.; Ayranci, E. A systematic study on the changes in properties of an activated carbon cloth upon polarization. Electrochim. Acta 2011, 56, 2184-2189. [CrossRef]

60. Stoychev, D.; Papoutsis, A.; Kelaidopoulou, A.; Kokkinidis, G.; Milchev, A. Electrodeposition of platinum on metallic and nonmetallic substrates - selection of experimental conditions. Mater. Chem. Phys. 2001, 72, 360-365. [CrossRef]

61. Corduneanu, O.; Diculescu, V.C.; Chiorcea-Paquim, A.-M.; Oliveira-Brett, A.-M. Shape-controlled palladium nanowires and nanoparticles electrodeposited on carbon electrodes. J. Electroanal. Chem. 2008, 624, 97-108. [CrossRef]

62. Roca-Ayats, M.; Yeung, K.L.; Hernández-Caricol, M.; Chen, W.Y.; Deng, R.; Fierro, J.L.G.; Lázaro, M.J.; Martínez-Huerta, M.V. Titanium carbonitride-graphene composites assembled with organic linkers as electrocatalytic supports for methanol oxidation reaction. Catal. Today 2020, 356, 101-109. [CrossRef]

63. Xiao, Y.; Fu, Z.; Zhan, G.; Pan, Z.; Xiao, C.; Wu, S.; Chen, C.; Hu, G.; Wei, Z. Increasing Pt methanol oxidation reaction activity and durability with a titanium molybdenum nitride catalyst support. J. Power Sources 2015, 273, 33-40. [CrossRef]

64. Shao, Y.; Wang, J.; Kou, R.; Engelhard, M.; Liu, J.; Wang, Y.; Lin, Y. The corrosion of PEM fuel cell catalyst supports and its implications for developing durable catalysts. Electrochim. Acta 2009, 54, 3109-3114. [CrossRef]

65. Sharma, S.; Pollet, B.G. Support materials for PEMFC and DMFC electrocatalysts-A review. J. Power Sources 2012, 208, 96-119. [CrossRef]

66. Roca-Ayats, M.; García, G.; Peña, M.A.; Martínez-Huerta, M.V. Titanium carbide and carbonitride electrocatalyst supports: Modifying Pt-Ti interface properties by electrochemical potential cycling. J. Mater. Chem. A 2014, 2, 18786-18790. [CrossRef]

67. Zhao, G.; Zhao, T.; Yan, X.; Zeng, L.; Xu, J. Ordered Mesoporous Carbon/Titanium Carbide Composites as Support Materials for Platinum Catalysts. Energy Technol. 2016, 4, 1064-1070. [CrossRef]

68. Mentus, S.V. Electrochemical response of a composite Pt/TiO2 layer formed potentiodynamically on titanium surfaces. Electrochim. Acta 2005, 50, 3609-3615. [CrossRef] 
69. Fu, Y.; Wei, Z.D.; Chen, S.G.; Li, L.; Feng, Y.C.; Wang, Y.Q.; Ma, X.L.; Liao, M.J.; Shen, P.K.; Jiang, S.P. Synthesis of Pd/TiO2 nanotubes/Ti for oxygen reduction reaction in acidic solution. J. Power Sources 2009, 189, 982-987. [CrossRef]

70. Chetty, R.; Scott, K. Catalysed titanium mesh electrodes for ethylene glycol fuel cells. J. Appl. Electrochem. 2007, 37, 1077-1084. [CrossRef]

71. Abraham, B.G.; Chetty, R. Design and fabrication of a quick-fit architecture air breathing direct methanol fuel cell. Int. J. Hydrogen Energy 2021, 46, 6845-6856. [CrossRef]

72. Chetty, R.; Scott, K. Direct ethanol fuel cells with catalysed metal mesh anodes. Electrochim. Acta 2007, 52, 4073-4081. [CrossRef]

73. Chetty, R.; Scott, K. Dimethoxymethane and trimethoxymethane as alternative fuels for fuel cells. J. Power Sources 2007, 173, 166-171. [CrossRef]

74. Avasarala, B.; Haldar, P. On the stability of TiN-based electrocatalysts for fuel cell applications. Int. J. Hydrogen Energy 2011, 36, 3965-3974. [CrossRef]

75. Kim, B.-K.; Seo, D.; Lee, J.Y.; Song, H.; Kwak, J. Electrochemical deposition of Pd nanoparticles on indium-tin oxide electrodes and their catalytic properties for formic acid oxidation. Electrochem. Commun. 2010, 12, 1442-1445. [CrossRef]

76. Song, Y.-J.; Han, S.-B.; Lee, J.-M.; Park, K.-W. PtRu alloy nanostructure electrodes for methanol electrooxidation. J. Alloys Compd. 2009, 473, 516-520. [CrossRef]

77. Lu, X.; Hu, J.; Foord, J.S.; Wang, Q. Electrochemical deposition of Pt-Ru on diamond electrodes for the electrooxidation of methanol. J. Electroanal. Chem. 2011, 654, 38-43. [CrossRef]

78. Mavrokefalos, C.K.; Hasan, M.; Khunsin, W.; Schmidt, M.; Maier, S.A.; Rohan, J.F.; Compton, R.G.; Foord, J.S. Electrochemically modified boron-doped diamond electrode with Pd and Pd-Sn nanoparticles for ethanol electrooxidation. Electrochim. Acta 2017, 243, 310-319. [CrossRef]

79. Mavrokefalos, C.K.; Hasan, M.; Rohan, J.F.; Foord, J.S. Enhanced Mass Activity and Stability of Bimetallic Pd-Ni Nanoparticles on Boron-Doped Diamond for Direct Ethanol Fuel Cell Applications. ChemElectroChem 2018, 5, 455-463. [CrossRef]

80. Abraham, B.G.; Bhaskaran, R.; Chetty, R. Electrodeposited Bimetallic (PtPd, PtRu, PtSn) Catalysts on Titanium Support for Methanol Oxidation in Direct Methanol Fuel Cells. J. Electrochem. Soc. 2020, 167, 024512. [CrossRef]

81. Centi, G.; Perathoner, S. The Role of Nanostructure in Improving the Performance of Electrodes for Energy Storage and Conversion. Eur. J. Inorg. Chem. 2009, 2009, 3851-3878. [CrossRef]

82. Ye, F.; Chen, L.; Li, J.; Li, J.; Wang, X. Shape-controlled fabrication of platinum electrocatalyst by pulse electrodeposition Electrochem. Commun. 2008, 10, 476-479. [CrossRef]

83. Li, J.; Ye, F.; Chen, L.; Wang, T.; Li, J.; Wang, X. A study on novel pulse preparation and electrocatalytic activities of Pt/C-Nafion electrodes for proton exchange membrane fuel cell. J. Power Sources 2009, 186, 320-327. [CrossRef]

84. Zhang, H.; Zhou, W.; Du, Y.; Yang, P.; Wang, C. One-step electrodeposition of platinum nanoflowers and their high efficient catalytic activity for methanol electro-oxidation. Electrochem. Commun. 2010, 12, 882-885. [CrossRef]

85. Jia, F.; Wong, K.; Zhang, L. Electrochemical Synthesis of Nanostructured Palladium of Different Morphology Directly on Gold Substrate through a Cyclic Deposition/Dissolution Route. J. Phys. Chem. C 2009, 113, 7200-7206. [CrossRef]

86. Jia, F.; Wong, K.; Du, R. Direct growth of highly catalytic palladium nanoplates array onto gold substrate by a template-free electrochemical route. Electrochem. Commun. 2009, 11, 519-521. [CrossRef]

87. Yao, Z.; Zhu, M.; Jiang, F.; Du, Y.; Wang, C.; Yang, P. Highly efficient electrocatalytic performance based on Pt nanoflowers modified reduced graphene oxide/carbon cloth electrode. J. Mater. Chem. 2012, 22, 13707. [CrossRef]

88. Luo, X.; Liu, Y.; Zhang, H.; Yang, B. Shape-selective synthesis and facet-dependent electrocatalytic activity of CoPt3 nanocrystals. CrystEngComm 2012, 14, 3359. [CrossRef]

89. Zhang, S.; Shao, Y.; Yin, G.; Lin, Y. Recent progress in nanostructured electrocatalysts for PEM fuel cells. J. Mater. Chem. A 2013, 1, 4631. [CrossRef]

90. Tian, N.; Zhou, Z.-Y.; Sun, S.-G.; Ding, Y.; Wang, Z.L. Synthesis of Tetrahexahedral Platinum Nanocrystals with High-Index Facets and High Electro-Oxidation Activity. Science 2007, 316, 732-735. [CrossRef]

91. Tian, N.; Zhou, Z.-Y.; Sun, S.-G. Electrochemical preparation of Pd nanorods with high-index facets. Chem. Commun. 2009, 1502-1504. [CrossRef] [PubMed]

92. Tian, N.; Zhou, Z.-Y.; Yu, N.-F.; Wang, L.-Y.; Sun, S.-G. Direct Electrodeposition of Tetrahexahedral Pd Nanocrystals with High-Index Facets and High Catalytic Activity for Ethanol Electrooxidation. J. Am. Chem. Soc. 2010, 132, 7580-7581. [CrossRef]

93. Hsu, I.J.; Esposito, D.V.; Mahoney, E.G.; Black, A.; Chen, J.G. Particle shape control using pulse electrodeposition: Methanol oxidation as a probe reaction on Pt dendrites and cubes. J. Power Sources 2011, 196, 8307-8312. [CrossRef]

94. Maniam, K.K.; Chetty, R. Palladium Nanodendrites Deposited on Electrochemically Activated Carbon Based Support for Electrocatalytic Applications. ECS Trans. 2014, 61, 11-20. [CrossRef]

95. Maniam, K.K.; Chetty, R. Electrochemical synthesis of palladium dendrites on carbon support and their enhanced electrocatalytic activity towards formic acid oxidation. J. Appl. Electrochem. 2015, 45, 953-962. [CrossRef]

96. Abraham, B.G.; Maniam, K.K.; Kuniyil, A.; Chetty, R. Electrocatalytic Performance of Palladium Dendrites Deposited on Titania Nanotubes for Formic Acid Oxidation. Fuel Cells 2016, 16, 656-661. [CrossRef]

97. Maniam, K.K.; Muthukumar, V.; Chetty, R. Electrodeposition of dendritic palladium nanostructures on carbon support for direct formic acid fuel cells. Int. J. Hydrogen Energy 2016, 41, 18602-18609. [CrossRef] 
98. Muthukumar, V.; Chetty, R. Morphological transformation of electrodeposited Pt and its electrocatalytic activity towards direct formic acid fuel cells. J. Appl. Electrochem. 2017, 47, 735-745. [CrossRef]

99. Muthukumar, V.; Chetty, R. Electrodeposited Pt-Pd dendrite on carbon support as anode for direct formic acid fuel cells. Ionics 2018, 24, 3937-3947. [CrossRef]

100. Martín, A.J.; Chaparro, A.M.; Gallardo, B.; Folgado, M.A.; Daza, L. Characterization and single cell testing of Pt/C electrodes prepared by electrodeposition. J. Power Sources 2009, 192, 14-20. [CrossRef]

101. Maniam, K.K.; Muthukumar, V.; Chetty, R. Approaches towards improving the dispersion of electrodeposited palladium on carbon supports. Energy Procedia 2014, 54, 281-291. [CrossRef]

102. Maniam, K.K.; Chetty, R. Electrodeposited palladium nanoflowers for electrocatalytic applications. Fuel Cells 2013, 13, 1196-1204. [CrossRef]

103. Maniam, K.K. Development of Shape Controlled Palladium Structures as Electrocatalysts for Fuel Cell Applications. Ph.D. Thesis, Indian Institute of Technology Madras, Chennai, India, 2013.

104. Abraham, B.G.; Chetty, R. Influence of electrodeposition techniques and parameters towards the deposition of Pt electrocatalysts for methanol oxidation. J. Appl. Electrochem. 2021, 51, 503-520. [CrossRef]

105. Mattarozzi, L.; Cattarin, S.; Comisso, N.; Gerbasi, R.; Guerriero, P.; Musiani, M.; Vázquez-Gómez, L. Preparation of compact and porous Pd-Ni alloys and study of their performances for ethanol oxidation in alkali. Electrochim. Acta 2019, 307, 503-511. [CrossRef]

106. Gharib, A.; Arab, A. Electrodeposited Pd, PdCd, and Pd Bi nanostructures: Preparation, characterization, corrosion behavior, and their electrocatalytic activities for formic acid oxidation. J. Electroanal. Chem. 2020, 866, 114166. [CrossRef]

107. Sadek, M.; Abd El-Lateef, H.M.; Mohran, H.S.; Elrouby, M. A promising star-like PtNi and coral reefs-like PtCo nano-structured materials for direct methanol fuel cell application. Electrochim. Acta 2021, 399, 139370. [CrossRef]

108. He, P.; Liu, H.; Li, Z.; Li, J. Electrodeposition of Platinum in Room-Temperature Ionic Liquids and Electrocatalytic Effect on Electro-oxidation of Methanol. J. Electrochem. Soc. 2005, 152, E146. [CrossRef]

109. Abbott, A.P.; McKenzie, K.J. Application of ionic liquids to the electrodeposition of metals. Phys. Chem. Chem. Phys. 2006, 8, 4265-4279. [CrossRef] [PubMed]

110. Wei, L.; Fan, Y.J.; Tian, N.; Zhou, Z.Y.; Zhao, X.Q.; Mao, B.W.; Sun, S.G. Electrochemically shape-controlled synthesis in deep eutectic solvents-A new route to prepare Pt nanocrystals enclosed by high-index facets with high catalytic activity. J. Phys. Chem. C 2012, 116, 2040-2044. [CrossRef]

111. Wei, L.; Mao, Y.J.; Wei, Y.S.; Li, J.W.; Nie, X.M.; Zhao, X.S.; Fan, Y.J.; Sun, S.G. Concentration-Mediated Shape Evolution of Palladium Nanocrystals and Their Structure-Electrocatalytic Functionality. Cryst. Growth Des. 2019, 19, 1532-1539. [CrossRef]

112. Wei, L.; Fan, Y.-J.; Wang, H.-H.; Tian, N.; Zhou, Z.-Y.; Sun, S.-G. Electrochemically shape-controlled synthesis in deep eutectic solvents of Pt nanoflowers with enhanced activity for ethanol oxidation. Electrochim. Acta 2012, 76, 468-474. [CrossRef]

113. Wei, L.; Zhou, Z.Y.; Chen, S.P.; Xu, C.D.; Su, D.; Schuster, M.E.; Sun, S.G. Electrochemically shape-controlled synthesis in deep eutectic solvents: Triambic icosahedral platinum nanocrystals with high-index facets and their enhanced catalytic activity. Chem. Commun. 2013, 49, 11152-11154. [CrossRef]

114. Hammons, J.A.; Muselle, T.; Ustarroz, J.; Tzedaki, M.; Raes, M.; Hubin, A.; Terryn, H. Stability, assembly, and particle/solvent interactions of Pd nanoparticles electrodeposited from a deep eutectic solvent. J. Phys. Chem. C 2013, 117, 14381-14389. [CrossRef]

115. Wei, L.; Xu, C.D.; Huang, L.; Zhou, Z.Y.; Chen, S.P.; Sun, S.G. Electrochemically Shape-Controlled Synthesis of Pd ConcaveDisdyakis Triacontahedra in Deep Eutectic Solvent. J. Phys. Chem. C 2016, 120, 15569-15577. [CrossRef]

116. Espino-López, I.E.; Romero-Romo, M.; de Oca-Yemha, M.G.M.; Morales-Gil, P.; Ramírez-Silva, M.T.; Mostany, J.; Palomar-Pardavé, M. Palladium Nanoparticles Electrodeposition onto Glassy Carbon from a Deep Eutectic Solvent at 298 K and Their Catalytic Performance toward Formic Acid Oxidation. J. Electrochem. Soc. 2019, 166, D3205-D3211. [CrossRef]

117. Fomin, A. Studies on the Electrodeposition of Aluminium from Different Air and Water Stable Ionic Liquids. Ph.D. Thesis, Clausthal University of Technology, Clausthal-Zellerfeld, Germany, 2010. Available online: https://d-nb.info/1008342475/34 (accessed on 28 September 2021).

118. Kamarudin, S.K.; Achmad, F.; Daud, W.R.W. Overview on the application of direct methanol fuel cell (DMFC) for portable electronic devices. Int. J. Hydrogen Energy 2009, 34, 6902-6916. [CrossRef]

119. Alias, M.S.; Kamarudin, S.K.; Zainoodin, A.M.; Masdar, M.S. Active direct methanol fuel cell: An overview. Int. J. Hydrogen Energy 2020, 45, 19620-19641. [CrossRef]

120. Shao, Z.-G.; Lin, W.-F.; Zhu, F.; Christensen, P.A.; Zhang, H.; Yi, B. A tubular direct methanol fuel cell with Ti mesh anode. J. Power Sources 2006, 160, 1003-1008. [CrossRef]

121. Mallick, R.K.; Thombre, S.B. Performance of passive DMFC with expanded metal mesh current collectors. Electrochim. Acta 2017, 243, 299-309. [CrossRef]

122. Masdar, M.S.; Dedikarni; Zainoodin, A.M.; Rosli, M.I.; Kamarudin, S.K.; Daud, W.R.W. Performance and stability of single and 6-cell stack passive direct methanol fuel cell (DMFC) for long-term operation. Int. J. Hydrogen Energy 2017, 42, 9230-9242. [CrossRef]

123. Hashim, N.; Kamarudin, S.K.; Daud, W.R.W. Design, fabrication and testing of a PMMA-based passive single-cell and a multi-cell stack micro-DMFC. Int. J. Hydrogen Energy 2009, 34, 8263-8269. [CrossRef] 
124. Wala, M.; Simka, W. Effect of anode material on electrochemical oxidation of low molecular weight alcohols-A review. Molecules 2021, 26, 2144. [CrossRef]

125. Wei, M.; Chan, S.H.; Mayyas, A.; Lipman, T. Deployment and Capacity Trends for Stationary Fuel Cell Systems in the USA. In Fuel Cells: Data, Facts and Figures; Wiley-VCH Verlag GmbH \& Co. KGaA.: Weinheim, Germany, 2016; pp. 257-269.

126. Prado, R.; Weber, C.C. Applications of Ionic Liquids. In Application, Purification, and Recovery of Ionic Liquids; Kuzmina, O., Hallett, J.P., Eds.; Elsevier: Amsterdam, The Netherlands, 2016; pp. 1-58. [CrossRef]

127. European Commission. Study on the EU's List of Critical Raw Materials (2020)_Final Report; European Commission: Brussels, Belgium, 2020. 